\title{
Ostracods from freshwater and brackish environments of the Carboniferous of the Midland Valley of Scotland: the early colonization of terrestrial water bodies
}

\author{
C. E. BENNETT* ${ }^{*}$, D. J. SIVETER*, S. J. DAVIES*, M. WILLIAMS*, \\ I. P. WILKINSON, M. BROWNE \& C. G. MILLER\# \\ * Department of Geology, University of Leicester, University Road, Leicester, LE1 7RH, UK. \\ $\S$ British Geological Survey, Keyworth, Nottingham, NG12 5GG, UK. \\ 『British Geological Survey, Murchison House, West Mains Road, Edinburgh, EH9 3LA, UK. \\ \#Department of Palaeontology, Natural History Museum, Cromwell Road, London, SW7 5BD, UK.
}

(Received 22 September 2010; accepted 5 February 2011; first published online 9 September 2011)

\begin{abstract}
The Mississippian Strathclyde Group of the Midland Valley of Scotland yields some of the earliest non-marine ostracods. The succession records shallow marine, deltaic, estuarine, lagoonal, lacustrine, fluvial and swamp environments representing a series of staging-posts between fully marine and limnetic settings. Macrofossils and ostracods are assigned to marine, marginal marine, brackish and freshwater environments based on their faunal assemblage patterns. Key brackish to freshwater ostracods are Geisina arcuata, Paraparchites circularis n. sp., Shemonaella ornata n. sp. and Silenites sp. A, associated with the bivalves Anthraconaia, Carbonicola, Cardiopteridium, Curvirimula, Naiadites, the microconchid 'Spirorbis', Spinicaudata and fish. Many Platycopina and Paraparchiticopina ostracods are interpreted as euryhaline, which corresponds with their occurrence in marine to coastal plain water bodies, and supports the 'estuary effect' hypothesis of non-marine colonization. The success of non-marine colonization by ostracods was dependent on the intrinsic adaptations of ostracod species to lower salinities, such as new reproductive strategies and the timing of extrinsic mechanisms to drive non-marine colonization, such as sea-level change. The genus Carbonita is the oldest and most common freshwater ostracod, and went on to dominate freshwater environments in the Late Palaeozoic.
\end{abstract}

Keywords: ostracods, Mississippian, freshwater, palaeoenvironment, terrestrialization.

\section{Introduction}

The colonization of non-marine water bodies by animals was one of the major ecological radiations of life. However, there is little known about the early colonization of the non-marine realm by ostracods, which are one of the most abundant animal groups. Ostracods are numerous, widespread and diverse in non-marine and marine waters today. Ostracods occur in the fossil record from the Early Ordovician onwards (Salas, Vannier \& Williams, 2007; Siveter, 2008) and appear to have been entirely marine during the Early Palaeozoic (for example see Williams et al. 2003). Their ecological migration from marine to freshwater aquatic environments occurred during the Late Palaeozoic, with the most complete record of this transition in the Carboniferous (Bennett, 2008). Putative brackish water ostracods have been recorded in the Silurian (Siveter, 1984; Clarkson, Harper \& Hoey, 1998; Floyd \& Williams, 2003), with more frequent attempts at colonizing brackish waters being recorded from the Late Devonian onwards (for example Bless, 1983; Bless, Streel \& Becker, 1988; Williams et al. 2006).
In the Late Silurian to Devonian a non-marine macrofossil lacustrine fauna (including freshwater fish and arthropods) became established worldwide, but it was not until the Carboniferous that most non-marine terrestrial environments were colonized (Buatois et al. 1998). The earliest Late Palaeozoic arthropods that are possibly taxonomically 'close' to ostracods and which apparently colonized freshwater are leperditicopes, a group which also originated in the Early Ordovician and which are recorded from Early Devonian brackish and putative freshwater environments (Friend \& MoodyStuart, 1970; Friedman \& Lundin, 1998; Knox \& Gordon, 1999). The timing of non-marine colonization in the Carboniferous by invertebrate detritus-feeders can be linked to the timing of land plant evolution (Bateman et al. 1998; Buatois et al. 1998). The 'passive' versus 'active' (Gray, 1988) nature of invertebrate non-marine colonization is key to understanding the mechanism of this ostracod radiation event, that is, whether invertebrates were passively stranded in coastal plain water bodies that freshened over time or if they exploited the food available from the land and actively activity adapted to freshwater conditions.

Living non-marine ostracods belong to the podocope superfamilies Cypridoidea, Darwinuloidea and Cytheroidea, all of which have possible Late Palaeozoic origins. The Palaeozoic Carbonitoidea may be related 
to the Cypridoidea or Darwinuloidea, and a group of non-marine Cytheroidea (limnocytherids) occur in the Late Carboniferous (Carbonel et al. 1988; Horne, 2003). The migration from marine to freshwater by the ostracod Carbonita Strand, 1928 first occurred during the Carboniferous; from brackish-influenced environments in the Mississippian (Pollard, 1966; Anderson, 1970; Bless \& Pollard; 1973; Sohn, 1985; Tibert \& Scott, 1999), to subsequently occupy a wide range of freshwater environments by the Pennsylvanian (Schultze, Maples \& Cunningham, 1994; Vannier, Thiery \& Racheboeuf, 2003; Schäfer, 2007). Herein, Carbonita is recorded from the early Mississippian in what are interpreted as freshwater sediments. Along with darwinuloideans, the carbonitoideans radiated to a high diversity of species in the Late Carboniferous and Permian (Carbonel et al. 1988; Horne, 2003) and were the most successful Late Palaeozoic ostracods in freshwater environments.

This study draws on a range of palaeontological, sedimentological and palaeoecological data from the Carboniferous of the Midland Valley of Scotland (MVS) to assess: (1) the absolute range of environments that ostracods were colonizing during the Carboniferous; (2) the types of ostracods that were making this transition and whether or not their adaptation was of short-term or long-term success; and (3) the possible mechanisms, both intrinsic (genetic) and extrinsic (environmental), that were driving or facilitating this ecological shift.

\section{Geological background}

The Strathclyde Group of the MVS was deposited in a range of environments, from shallow marine, restricted marine lagoons and estuaries, to coastal floodplains, fluvial systems and freshwater lakes and swamps (Browne et al. 1999). The well-preserved and abundant macrofossils and ostracods in the Strathclyde Group make it an ideal sequence to study a marine to non-marine ecological shift during the Mississippian. At this time the MVS was situated on the margins of a restricted marine seaway at an equatorial latitude (Fig. 1). Siliciclastic sediment, sourced mainly from the highlands to the north was deposited in prograding alluvial to lacustrine deltaic systems, with infrequent marine transgressions (Browne et al. 1999). A study of the older (early Mississippian, Courceyan) Ballagan Formation demonstrated ostracods in hypersaline and brackish water bodies (Williams et al. 2005, 2006), associated with possible freshwater to brackish algal palynomorphs (Stephenson et al. 2004a,b).

The formations of the Strathclyde Group are correlated across Fife in Scotland using distinctive marine horizons and non-marine limestones (Browne et al. 1999; Wilson, 1989). The group is well dated by lava flows, lapilli-tuffs and intrusions and by the presence of spores (Monaghan \& Parrish, 2005; Owens et al. 2005; Stephenson et al. 2004b; Fig. 1). The Anstruther Formation has the most non-marine limestones (Fig. 2); the Pittenweem Formation contains fully marine and marginal marine horizons ('marine bands') belonging to the Macgregor Marine Bands (Wilson, 1989); the Sandy Craig Formation is essentially non-marine; and the Pathhead Formation contains the thickest fully marine horizons.

Twenty-five ostracod species are reported from the Strathclyde Group, belonging to the orders Podocopida, Leiocopida, Palaeocopida and Myodocopida (Table 1). Ostracods occur in a range of sediment types and faunal associations (Table 2). The single most diverse ostracod assemblage contains 14 species (Table 3). Ostracods are well preserved, with the exception of those from the Pittenweem Formation, in which most of the carapaces have been dissolved to leave only moulds, and only one species has been identified. The association of particular ostracod species within particular macrofaunal assemblages has been used to determine their ecology.

\section{Methodology}

The sedimentology and fauna were documented from a wide range of rock specimens together with 39 polished thin-sections (cut to a standard thickness of $30 \mu \mathrm{m}$ ) of samples derived from boreholes and field exposures. Ostracods picked from bedding plane surfaces were imaged using a Hitachi S-3600N Scanning Electron Microscope (SEM) at the University of Leicester. Some fossils were photographed on bedding plane surfaces using a Zeiss Axiocam light photography digital imaging system at the Natural History Museum, London.

A taphonomic assessment is important to interpret the ecology of macrofossils and ostracods. An ostracod thanatocoenosis is signalled by the presence of adults and juveniles of different instars, a high proportion of carapaces to single valves and the (rare) occurrence of open ('butterfly') carapaces. Mostly single or broken valves, stacked valves and a valve size bias signal a taphocoenosis (sensu Boomer, Horne \& Slipper, 2003). In the sedimentary logs and faunal association tables (Tables 2-5, Figs 3-5), all occurrences of a particular fauna are noted. The problem of apparent ecological ranges being obscured by transportation (Horne, 2003) is addressed by reference to the supposed ecologies of particular fossils, and the taphonomy is carefully considered when assigning an ecological range to any fossil group.

\section{Faunal assemblages and sedimentary environments}

The faunas of the Strathclyde Group can be grouped into recurrent assemblages (Tables 4, 5) and facies (Figs 3-6):

Type 1 Assemblage: a high-diversity assemblage of 11 ostracod species and crinoids, orthocones, bryozoans, brachiopods, trilobites, goniatites, gastropods, echinoids and bivalves and the feeding-dwelling trace 


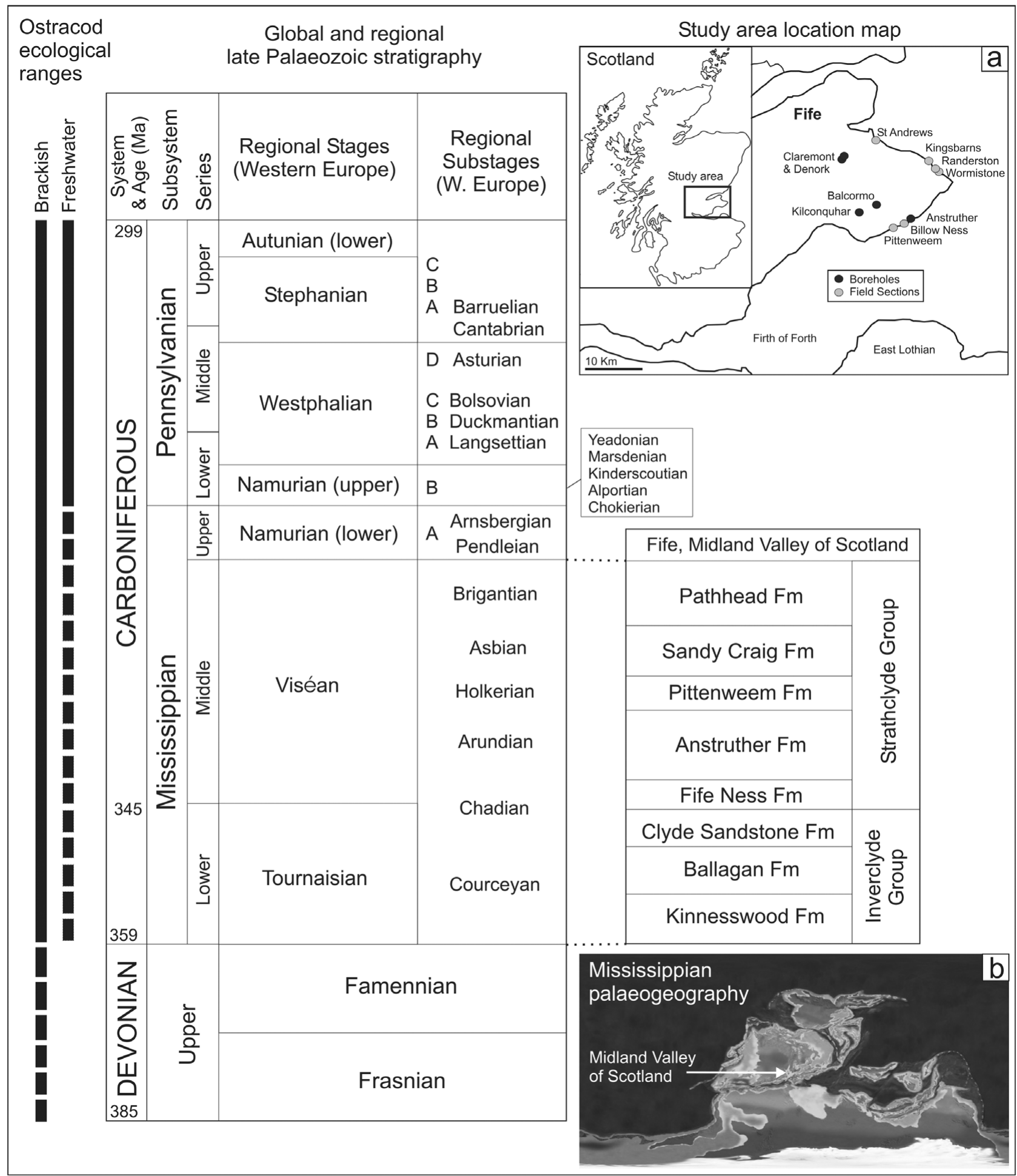

Figure 1. Late Devonian and Carboniferous lithostratigraphy for Fife in the Midland Valley of Scotland. Inset (a) shows the location map of sections studied; inset (b) shows Mississippian palaeogeography. The ecological radiation of ostracods relative to the chronostratigraphy is plotted in terms of their occurrence in brackish and freshwater, from other published records. Solid lines represent a confident age assignment for brackish or freshwater conditions, dashed lines a tentative assignment or only rare occurrence. Carboniferous stratigraphy is adapted from Heckel \& Clayton (2006) for Western Europe and Browne et al. (1999) for Fife. Dates are from the International Commission of Stratigraphy timescale 2004. The Mississippian palaeogeographic map is for $340 \mathrm{Ma}$, downloaded from Prof. R. Blakey's website http://jan.ucc.nau.edu/ rcb7.

Chondrites (Table 4). The macrofaunal elements are mainly benthic, with rare nektonic elements such as cephalopods. Hollinella (Keslingella) radiata (Jones \& Kirkby, 1886) is the most common Type 1 Assemblage ostracod species. This assemblage occurs in Facies 1 and 3a; Facies 1 is fossiliferous limestones within thick (up to $10 \mathrm{~m}$ ) mudstone intervals or mudstones, with a diverse fauna (Fig. 3). The Pathhead Lower Marine Band has the highest faunal diversity; containing 30 macrofossil and 10 ostracod species. Only very rare 


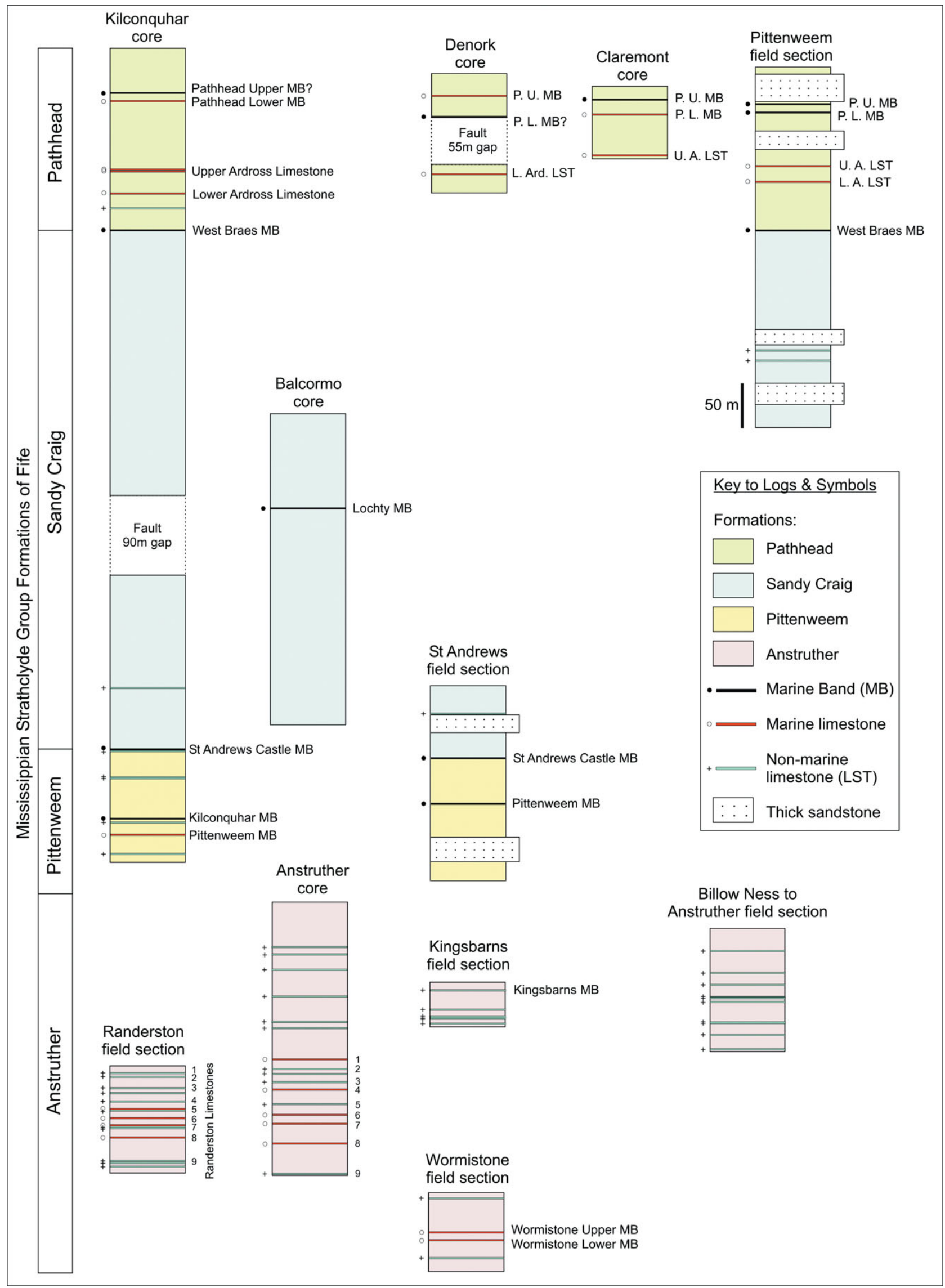

Figure 2. (Colour online) Borehole and field section correlation panel for the Strathclyde Group. Sandstone units (Facies 3a) with a thickness greater than $20 \mathrm{~m}$ are shown. British Geological Survey (BGS) boreholes, from 1964-1980, are stored at the BGS in Edinburgh. A sedimentary log and a list of macrofauna were described from these cores by BGS workers (additionally the Balcormo and Kilconquhar boreholes were also described by National Coal Board workers). Field samples were collected as part of this study between 2005 and 2008 . 
Table 1. Taxonomic scheme for the ostracods of the Strathclyde Group featured in this study. The higher classification follows Whatley et al. (1993), supplemented by consideration of Sohn (1985) for the Superfamily Carbonitoidea, and Dewey \& Fåhraeus (1987) for the Family Geisinidae

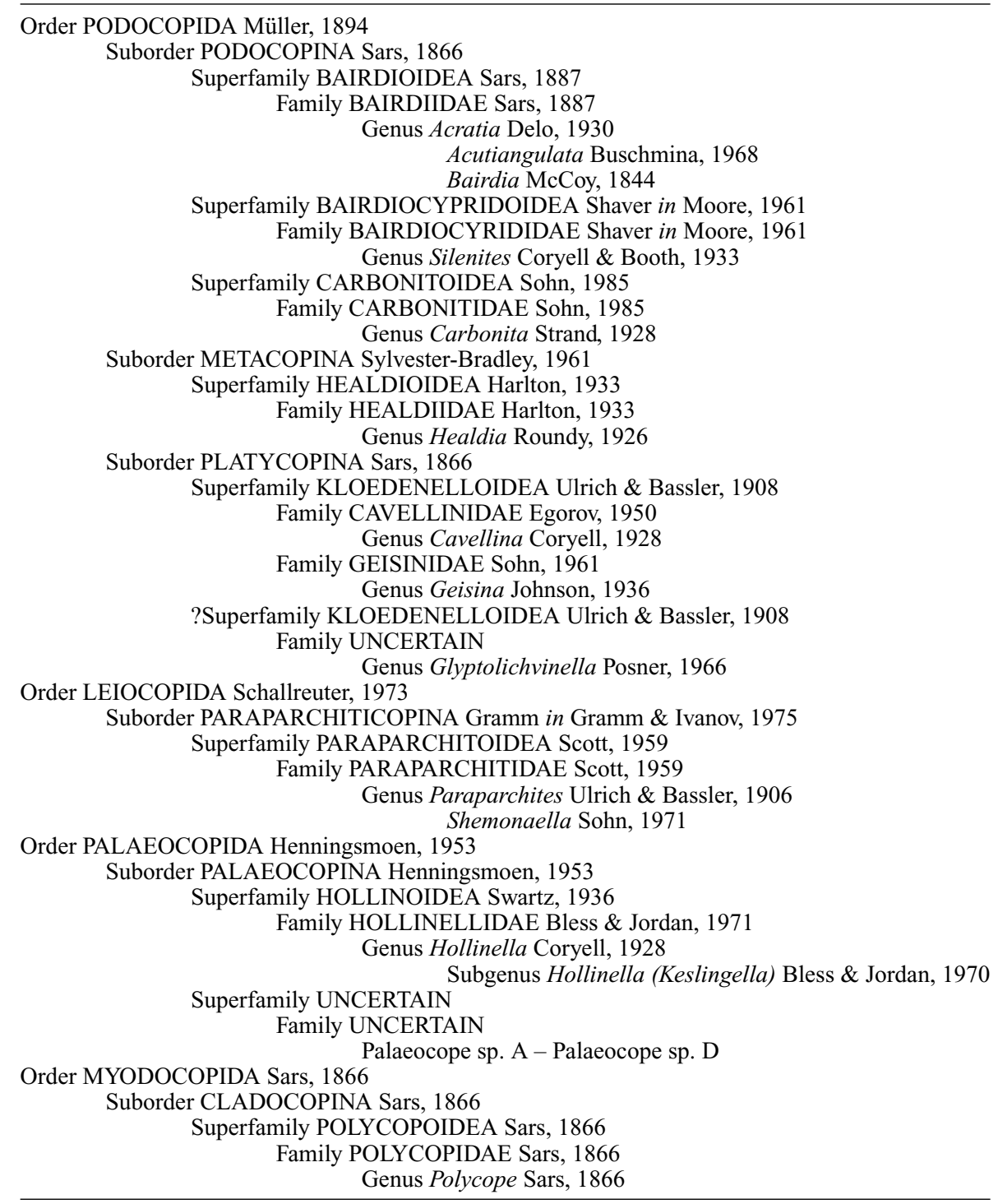

Type 1 Assemblage elements are present in Facies $3 \mathrm{a}$; thick, medium-coarse-grained, quartz arenite sandstone successions (from 10-26 $\mathrm{m}$ in thickness), present in sections of the formations studied (Fig. 2). Structures include channel forms, parallel laminations, large-scale cross-bedding (1.5 m height planar cross-beds) and extensive convolute-bedding (some convoluted units are $10 \mathrm{~m}$ thick) leading to a hummocky weathering pattern. In some cases the tops of large cross-beds are convoluted.

Type 2 Assemblage: includes six ostracod species, the brachiopod Lingula, the bivalves Myalina, Schizodus, Sanguinolites and fish (Table 4). Lingula is most common in the Type 1 Assemblage, but also occurs in Type 2, 3 and 4 assemblages (Table 5), as do Schizodus and Sanguinolites. The assemblage is typified by an association of the ostracods Cavellina valida (Jones, Kirkby \& Brady, 1884), Shemonaella elongata n. sp. and palaeocope sp. A. A Type 2 or low-diversity Type 1 Assemblage occurs in Facies 2 mudstones and limestones, most common in the Pathhead and Pittenweem formations (Fig. 3).

Type 3 Assemblage: comprises 11 ostracod species, the most common being Paraparchites circularis $\mathrm{n}$. sp., 'Spirorbis', the bivalves Curvirimula scotica and Naiadites obesus and fish (Table 4). Naiadites is the most common and 'Spirorbis' is frequently associated with Curvirimula, Naiadites, fish and plant debris (Table 5). Modern Spirorbis is a polychaete worm, but Palaeozoic 'spirorbids' are related to lophophorates (Microconchida; Taylor \& Vinn, 2006), encrust hard substrates (such as stromatolites: Burchette \& Riding, 1977) and were probably suspension feeders. Specimens are planispiral (230-2000 $\mu \mathrm{m}$ diameter) evolute, prostrate discoidal calcareous tubes. Type 3 Assemblage elements occur in Facies 4; mudstones and limestones such as Naiadites 'mussel bands', are particularly common in the Pittenweem (Fig. 3) and Anstruther (Fig. 4) formations. These mussel bands represent a taphocoenosis, but Naiadites is also 
Table 2. Ostracod material, sediments and macrofaunal associations

\begin{tabular}{|c|c|c|c|c|}
\hline Species & Material \& Samples & Location & Sediments & $\begin{array}{c}\text { Faunal } \\
\text { Associations }\end{array}$ \\
\hline Acratia sp. A. & $\begin{array}{l}1 \text { specimen, (juv., SV, partly broken), sample EN } \\
4818\end{array}$ & Claremont core & mudstone & Type $3-4$ \\
\hline Acutiangulata sp. A. & 1 specimen (juv., C), EN 4885 & Claremont core & Pathhead Lower MB & Type 1 \\
\hline Bairdia submucronata & $\begin{array}{l}10 \text { specimens, EN 4884, EN } 4885 \text { and EN } 4886 \\
\text { (Cs) }\end{array}$ & Claremont core & Pathhead Lower MB & Type 1 \\
\hline Carbonita bairdioides & A few specimens, 6E 6562 (SVs) & Balcormo core & BBI & Type 4 \\
\hline Carbonita cf. fabulina & 1 specimen, SE 8538 (C) & Kilconquhar core & mudstone & Type 4 \\
\hline Carbonita cf. humilis & 2 specimens, SE 8476 (Cs) & Kilconquhar core & mudstone & Type 4 \\
\hline Carbonita cf. inflata & 1 specimen, SE 8413 (C) & Kilconquhar core & BBI & Type 4 \\
\hline Carbonita sp. & $\begin{array}{l}1000 \text { s of specimens at a generic level, mostly } \\
\text { poorly preserved }\end{array}$ & $\begin{array}{l}\text { Anstruther, } \\
\text { Kilconquhar \& } \\
\text { Balcormo cores }\end{array}$ & mudstone, limestone & Types $2-4$ \\
\hline Cavellina benniei & $\begin{array}{l}1 \text { specimen, EN } 4841 \text { (adult, C) } \\
3 \text { specimens, EK } 9601 \text { ( } 1 \text { C, } 1 \text { SV, } 1 \text { juv. SV) }\end{array}$ & $\begin{array}{l}\text { Claremont core } \\
\text { Billow-Ness - Ans. } \\
\text { Fs }\end{array}$ & $\begin{array}{l}\text { mudstone } \\
\text { mudstone }\end{array}$ & $\begin{array}{l}\text { Type } 1 \\
\text { none }\end{array}$ \\
\hline Cavellina valida & 1000 s of specimens, mostly Cs, many juvs & $\begin{array}{l}\text { Kilconquhar, } \\
\text { Claremont \& } \\
\text { Denork cores }\end{array}$ & mudstone & Types $1-3$ \\
\hline Cavellina sp. & 100 s of specimens & $\begin{array}{l}\text { most cores and } \\
\text { sections }\end{array}$ & mudstone & Type $2-3$ \\
\hline \multirow[t]{3}{*}{ Geisina arcuata } & 4 specimens, EN 4818 (SV), EN 4827 (Cs) & Claremont core & siltstone, mudstone & Types 2-4 \\
\hline & 2 specimens EN 5257 (SV), EN 5272 (cast) & Denork core & mudstone & Types 3-4 \\
\hline & 1 specimen EK 9591 (SV) & Billow Ness - Ans. Fs & mudstone & Types 3-4 \\
\hline Glyptolichvinella spiralis & 1 specimen, field sample $20(\mathrm{LV})$ & Kingsbarns section & limestone & Type 4 \\
\hline Healdia cf. cuneata & 1 specimen, EN 4849 (juv., C) & Claremont core & Pathhead Lower MB & Type 1 \\
\hline Hollinella (K.) radiata & At least 20 specimens, 15 samples $(\mathrm{Cs})$ & Claremont core & Pathhead Lower MB & Type 1 \\
\hline Palaeocope sp. A & 100 s of specimens (Cs \& SVs) & $\begin{array}{l}\text { Denork, Claremont \& } \\
\text { Balcormo cores }\end{array}$ & siltstone, mudstone & Types $1-4$ \\
\hline Palaeocope sp. B & 5 specimens, EN 4805 (3 SVs), EN 4807 (C) & Claremont core & mudstone & Types 3-4 \\
\hline Palaeocope sp. C & $\begin{array}{l}3 \text { specimens, EN } 4848 \text { (C), EN } 4849 \text { (C) \& EN } \\
4856 \text { (juv. C) }\end{array}$ & Claremont core & Pathhead Lower MB & $\begin{array}{l}\text { lype } 2 \\
\text { Type } 1\end{array}$ \\
\hline Palaeocope sp. D & 1 specimen, EN 4787 (C, specimen now lost) & Claremont core & mudstone & none \\
\hline Paraparchites arm. & $\begin{array}{l}8 \text { specimens, EN } 5188 \text {, EN } 5197 \text { (SVs, dis. Cs, } \\
\text { moulds) }\end{array}$ & Denork core & mudstone & Types $1-2$ \\
\hline Paraparchites circ. n. sp. & $\begin{array}{l}\text { 1000s of specimens, SE } 8410,8411 \text { and } 8412 \\
\text { (SVs \& Cs) }\end{array}$ & & BBI, mudstone & Types 3-4 \\
\hline Polycope elegans $\mathrm{n} . \mathrm{sp}$. & $\begin{array}{l}26 \text { specimens, EN } 5329 \text { ( } 10 \text { Cs, } 10 \text { moulds) } \\
\text { EN } 5328 \text { (2 Cs, } 2 \text { SVs) } \\
\text { EN } 5327 \& \text { EN } 5326 \text { (one mould in each) }\end{array}$ & Denork core & $\begin{array}{l}\text { mudstone } \\
\text { mudstone } \\
\text { siltstone }\end{array}$ & $\begin{array}{l}\text { none } \\
\text { Types } 1-2 \\
\text { Type } 1\end{array}$ \\
\hline Shemonaella elongata $\mathrm{n} . \mathrm{sp}$. & 1000 s of specimens, many samples, Cs \& SVs & all formations & all sediments & Types $1-4$ \\
\hline Shemonaella ornata $\mathrm{n}$. sp. & $\begin{array}{l}6 \text { specimens, EN } 4818 \text { (four SVs), \& EN } \\
4804 \text { ( } 2 \text { Cs) }\end{array}$ & Claremont core & mudstone & Types $3-4$ \\
\hline Silenites sp. A & $\begin{array}{l}3 \text { specimens, EN } 5249 \text { (RV), EN } 5250 \text { (RV), SE } \\
\quad 8411 \text { (C) }\end{array}$ & $\begin{array}{l}\text { Denork, Kilconquhar } \\
\text { cores }\end{array}$ & siltstone, BBI & Types 3-4 \\
\hline
\end{tabular}

Sample numbers refer to sedimentary rocks containing the ostracods (from BGS boreholes, stored in Edinburgh). Faunal association indicates the ostracod occurrence in particular macrofaunal assemblages.

Abbreviations: C - carapace; SV - single valve; RV - right valve; LV - left valve; juv. - juvenile; dis - disarticulated; Ans. Fs - Anstruther field section; MB - Marine Band; BBI - blackband ironstone.

present in thanatocoenosis deposits of low-abundance, monospecific or low-diversity elements of Type 3 and 4 assemblages (Fig. 4).

Type 4 Assemblage: includes 15 ostracod species, most commonly Carbonita sp., the bivalves Anthraconaia, Carbonicola antique, C. elegans, Cardiopteridium and the branchiopod conchostracans Spinicaudata (Table 4). Curvirimula, Naiadites, fish and 'Spirorbis' occur in both Type 3 and 4 assemblages. Anthraconaia, Carbonicola and Cardiopteridium commonly occur as low-diversity assemblages associated with Naiadites, plant and fish debris (Bennison, 1960, 1961 and this study). Euestheria, Estheria and Leaia occur in mudstones, associated with plants, fish, Naiadites and ostracods (Table 5). Fish debris (fragments, scales and teeth) are ubiquitous in a range of faunal associations throughout the Strathclyde Group, but occur frequently with Type 3 and 4 assemblages (Table 5). The most complete specimen is a small fish jaw, with affinities to the actinopterygian Rhadinichthys ferrox Traquair ( $\mathrm{Z}$. Johanson pers. comm.).

Type 4 Assemblage elements are present in Facies 3b, 5,6 and 7. Facies $3 b$ is medium-grained, quartz arenite sandstone units (2-10 m in thickness), with Stigmaria roots and bioturbated bases and tops of beds, common in all studied sections. Sedimentary structures include sigmoidal surfaces, trough cross-bedding, planar crossbedding, current ripples and rare desiccation cracks. Sandstones are commonly interbedded with mudstones on a centimetre to millimetre scale. The thinner beds (commonly $1 \mathrm{~m}$ or less), compared to the thicker or convoluted beds of Facies $3 \mathrm{a}$, can be clearly distinguished at exposure. Low-diversity ichnofossil assemblages are most common in this facies and include Monocraterion, Arenicolites, Diplocraterion, Skolithos and Teichichnus and Palaeophycus and 
Table 3. Ostracod faunal associations of species from the Strathclyde Group

\begin{tabular}{|c|c|c|c|c|c|c|c|c|c|c|c|c|c|c|c|c|c|c|c|c|c|c|c|}
\hline & & 1 & 2 & 3 & 45 & 6 & 7 & 8 & 9 & 10 & 11 & 1213 & 14 & 15 & 16 & 17 & 18 & 19 & 20 & 2122 & 23 & 24 & 25 \\
\hline 1 & Acratia sp. A. & & & & & & & & & $\mathrm{X}$ & & $\mathrm{X}$ & & & & & & & & & $\mathrm{X}$ & $\mathrm{X}$ & \\
\hline 2 & Acutiangulata sp. A. & & & $\mathrm{X}$ & & & & & & $\mathrm{X}$ & & & & & & & & & & & & $\mathrm{X}$ & \\
\hline 3 & Bairdia submucronata & & $\mathrm{X}$ & & & & & & & $\mathrm{X}$ & & & & & & & & & & & & $\mathrm{X}$ & \\
\hline 4 & Carbonita bairdioides & & & & & & & & & $\mathrm{X}$ & & & & & & & & & & & & & \\
\hline 5 & Carbonita cf. fabulina & & $\mathrm{b}$ assc & ocia & ations & & & & & & & & & & & & & & & & & & \\
\hline 6 & Carbonita cf. humilis & no & $\mathrm{b}$ assc & cia & ations & & & & & & & & & & & & & & & & & & \\
\hline 7 & Carbonita cf. inflata & & & & & & & & & $\mathrm{X}$ & $\mathrm{X}$ & & & & & & & & & & & & \\
\hline 8 & Carbonita sp. & & & & & & & & & $\mathrm{X}$ & & $\mathrm{X}$ & & & & & & & & & & & \\
\hline 9 & Cavellina benniei & & & & & & & & & $\mathrm{X}$ & & & & $\mathrm{X}$ & & & & & & & & $\mathrm{X}$ & \\
\hline 10 & Cavellina valida & $\mathrm{X}$ & $X$ & & $\mathrm{X}$ & & $\mathrm{X}$ & $\mathrm{X}$ & $\mathrm{X}$ & & & $\mathrm{X}$ & $\mathrm{X}$ & $\mathrm{X}$ & $\mathrm{X}$ & & $\mathrm{X}$ & & & & $\mathrm{X}$ & $\mathrm{X}$ & \\
\hline 11 & Cavellina sp. & & & & & & & $\mathrm{X}$ & & & & $\mathrm{X}$ & & & & $\mathrm{X}$ & & $\mathrm{X}$ & & & $\mathrm{X}$ & $\mathrm{X}$ & \\
\hline 12 & Geisina arcuata & $\mathrm{X}$ & & & & & & $\mathrm{X}$ & & $\mathrm{X}$ & $\mathrm{X}$ & & & & & & & & & & $\mathrm{X}$ & $\mathrm{X}$ & $\mathrm{X}$ \\
\hline 13 & Glyptolichvinella spiralis & no & $\mathrm{b}$ assc & cia & ations & & & & & & & & & & & & & & & & & & \\
\hline 14 & Healdia cf. cuneata & & & & & & & & & $\mathrm{X}$ & & & & $\mathrm{X}$ & & & $\mathrm{X}$ & & & & & & \\
\hline 15 & Hollinella (Keslingella) radiata & & & & & & & & $\mathrm{X}$ & $\mathrm{X}$ & & & $\mathrm{X}$ & & $\mathrm{X}$ & & $\mathrm{X}$ & & & & & $\mathrm{X}$ & \\
\hline 16 & palaeocope sp. A & & & & & & & & & $\mathrm{X}$ & $\mathrm{X}$ & & & $\mathrm{X}$ & & $\mathrm{X}$ & & $\mathrm{X}$ & & & $\mathrm{X}$ & & $\mathrm{X}$ \\
\hline 17 & palaeocope sp. B & & & & & & & & & & $\mathrm{X}$ & & & & $\mathrm{X}$ & & & & & & & $\mathrm{X}$ & \\
\hline 18 & palaeocope sp. C & & & & & & & & & $\mathrm{X}$ & & & $\mathrm{X}$ & $\mathrm{X}$ & & & & & & & & $\mathrm{X}$ & \\
\hline 19 & palaeocope sp. D & & & & & & & & & & $\mathrm{X}$ & & & & $\mathrm{X}$ & & & & & & & $\mathrm{X}$ & \\
\hline 20 & Paraparchites armstrongianus & & & & & & & & & & & & & & & & & & & & & $\mathrm{X}$ & \\
\hline 21 & Paraparchites circularis n. sp. & & & & & & & & & & & & & & & & & & & & & & $\mathrm{X}$ \\
\hline 22 & Polycope elegans $\mathrm{n} . \mathrm{sp}$. & no & 0 assc & & ations & & & & & & & & & & & & & & & & & & \\
\hline 23 & Shemonaella ornata $\mathrm{n}$. sp. & $\mathrm{X}$ & & & & & & & & $\mathrm{X}$ & $\mathrm{X}$ & $\mathrm{X}$ & & & $\mathrm{X}$ & & & & & & & & $\mathrm{X}$ \\
\hline 24 & Shemonaella elongata $\mathrm{n}$. sp. & $\mathrm{X}$ & $\mathrm{X}$ & $\mathrm{X}$ & & & & & $\mathrm{X}$ & $\mathrm{X}$ & $\mathrm{X}$ & $\mathrm{X}$ & & $\mathrm{X}$ & $\mathrm{X}$ & $\mathrm{X}$ & $\mathrm{X}$ & $\mathrm{X}$ & $\mathrm{X}$ & & & & $\mathrm{X}$ \\
\hline 25 & Silenites sp. A. & & & & & & & & & & $\mathrm{X}$ & & & & $\mathrm{X}$ & & & & & $\mathrm{X}$ & $\mathrm{X}$ & $\mathrm{X}$ & \\
\hline
\end{tabular}

These data do not include the frequency of occurrences; this information is shown for four selected non-marine ostracods in Table 5 .

Planolites. Rare body fossils include Naiadites, fish, plants, 'Spirorbis', Lingula, Spinicaudata, Type 1 and Type 2 Assemblage bivalves and poorly preserved ostracods. Facies 5 sediments are mudstones, carbonaceous shales, siltstones and sandstones with plentiful plant debris; common in the Anstruther and Sandy Craig formations (Fig. 5a-h). The Type 4 Assemblage ostracods are most diverse in Facies 5.

Facies 6 sediments are blackband ironstones composed of alternating iron-rich mudstone (occasionally siltstone) laminae, black carbonaceous mudstone laminae and coal with abundant plant debris; present in sections of the Pathhead, Sandy Craig and Pittenweem formations (Fig. 5). Common fauna in this facies are Spinicaudata, Lingula, Curvirimula, fish, 'Spirorbis' and ostracods (Fig. 6a). Ostracods are mostly preserved as carapaces and occur on both ironstone and mudstone laminae, but are more common on the iron-rich laminae. Paraparchites circularis n. sp. occurs within a $20 \mathrm{~cm}$ thick blackband ironstone in great abundance, associated with plant debris, rare fish and rare Carbonita cf. inflata and Silenites sp. A. In this thanatocoenosis ostracod carapaces are randomly oriented; adult carapaces are most abundant, with some juveniles (Fig. 6a).

Coals and extensively rooted sandstones or siltstones ('seat-earths') are associated with Facies 6. No ostracods have been identified from coals although Carbonita is common in Pennsylvanian coal deposits elsewhere (see, for example, Bless \& Pollard, 1973; Sohn, 1977; Schäfer, 2007). The 'seat-earths' commonly underlie shaly coal or coal beds, range in thickness from $0.1-1 \mathrm{~m}$, and do not contain ostracods or macrofauna. The roots are composed of large $1 \mathrm{~cm}$ diameter siderite-filled vertical roots and smaller (millimetre thick) organic branching rootlets. Thin units with remnant sedimentary structures are common in all formations and are often overlain by cross-bedded or laminated sandstones. Thicker units (1 m thick) with pervasive root structures are prominent because the roots have destroyed any sedimentary structures. Three of these thick units are identified from field exposures of the Pittenweem and Sandy Craig formations and each is overlain by coals.

Facies 7 dolomitized algal limestones are most numerous in the Anstruther Formation (Fig. 2), and are either stromatolitic or of oncoidal-type concentric form. The fauna includes 'Spirorbis', fish and plant debris, coprolites, Naiadites, and the ostracods Carbonita sp., rare Glyptolichvinella spiralis, Shemonaella elongata $\mathrm{n}$. sp. and mostly indeterminate ostracods. Most limestone beds contain elements of both vertically stacked hemispheroids (stromatolites) and concentrically laminated spheroids (oncoids). Oncoids range in size (centimetres to millimetres), while stromatolites vary in form from laminated to well-formed hemispheroids. Vertically stacked hemispheroids have Cryptozoon-like club or columnar shapes in outline (Logan, Rezak \& Ginsburg, 1964) and some are brecciated at the top (probably owing to desiccation). The basal radius of the laminae increases upwards and domes at the top (Fig. 6b). The spaces between the hemispheroids and within desiccation cracks are filled with oncoids, detrital sediment, fish fragments and abundant ostracods. Freshwater stromatolites are typically composed of a diverse community of algae and microinvertebrates (Freytet \& Verrecchia, 1998). The Strathclyde Group limestones have been extensively dolomitized (Searl, 1991) and particular algal species cannot be determined. 
Table 4. The macrofossils and ostracods of the Strathclyde Group, grouped into their respective assemblage types

\begin{tabular}{|c|c|c|c|}
\hline \multicolumn{2}{|l|}{ TYPE 1 ASSEMBLAGE } & \multirow{2}{*}{$\begin{array}{l}\text { TYPE } 2 \text { ASSEMBLAGE } \\
\text { Ostracoda }\end{array}$} & \multirow{2}{*}{$\begin{array}{l}\text { TYPE } 4 \text { ASSEMBLAGE } \\
\text { Ostracoda }\end{array}$} \\
\hline Ostracoda & Brachiopoda & & \\
\hline Acutiangulata sp. A & Crurithyris & Cavellina sp. & Carbonita sp. \\
\hline Bairdia submucronata & Echinocorihus cf. purictatus & Geisina arcuata & Carbonita bairdioides \\
\hline Cavellina benniei & Lingula squariformis & palaeocope sp. A & Carbonita cf. fabulina \\
\hline Cavellina valida & Lingula mytilloides & palaeocope sp. B & Carbonita cf. humilis \\
\hline Healdia cf. cuneata & Lingula & Paraparchites armstrongianus & Carbonita cf. inflata \\
\hline Hollinella (Keslingella) radiata & Orbiculoidea cincta & Shemonaella siveteri $\mathrm{n}$. sp. & Cavellina benniei \\
\hline palaeocope sp. A & Orbiculoidea & Bivalvia & Cavellina valida \\
\hline palaeocope sp. C & Orthotetoid & Myalina & Cavellina sp. \\
\hline Paraparchites armstrongianus & Pleuropugnoides & Naiadites crassus & Geisina arcuata \\
\hline Polycope elegans $\mathrm{n} . \mathrm{sp}$. & Productus & Naiadites obesus & palaeocope sp. A \\
\hline Shemonaella siveteri $\mathrm{n} . \mathrm{sp}$. & Punctospirife & Naiadites & palaeocope sp. B \\
\hline Bivalvia & Schizophoria & Sanguinolites clavatus & Paraparchites circularis $\mathrm{n} . \mathrm{sp}$. \\
\hline Actinoptera persulata & Spirife & Sanguinolites costellaters & Shemonaella siveteri $\mathrm{n} . \mathrm{sp}$. \\
\hline Actinopteria & Spiriferellina & Sanguinolites plicatus & Shemonaella ornata $\mathrm{n}$. sp. \\
\hline Aviculopecten plicatus & Trigonoglossa scotia & Sanguinolites variabiles & Silenites sp. A \\
\hline Aviculopecten planoclathratis & Trigonoglossa & Sanguinolites & Bivalvia \\
\hline Aviculopecten cf. subconoideus & Gastropoda & Schizodus pentlandicus & Anthraconaia? kirki \\
\hline Aviculopecten & Donaldina & Schizodus & Carbonicola antiqua? \\
\hline Cypricardella $\mathrm{cf}$. rectangularis & Euphemites & Brachiopoda & Carbonicola elegans \\
\hline Cypricardella & Globroingulara & Lingula squamiformis & Carbonicola \\
\hline Edmondia senilis & Meekospira & Lingula mytilloides & Cardiopteridium \\
\hline Edmondia & Murchisonid & Lingula & Curvirimula cf. scotica \\
\hline Hemipecten & Naticopsis scotoburdigalensis? & Vertebrata & Curvirimula \\
\hline Leiptera & Naticopsis & fish fragments indet. & Naiadites obesus \\
\hline Limipecten & Pseudozygopleura cf. rugifera & Others & Naiadites \\
\hline Linoprotonia & Pseudozygopleura & coprolites & Branchiopoda \\
\hline Lithophaga lingualis & Retispira decurrata & Ichnolites & Estheria \\
\hline Lithophaga & Retispira striata & Arenicolites & Euestheria \\
\hline Modiolus sublamellosa & Retispira & Diplocraterion & Leaia \\
\hline Myalina & Scaphopoda & Monocraterion & Vertebrata \\
\hline Naiadites crassus & Dentalium & Palaeophycus & fish fragments indet. \\
\hline Nuculoid & Cnidaria & Planolites & actinopterigian jaw \\
\hline Nucleopus gibbosa & Lithostrotion junceum & Skolithos & Others \\
\hline Palaeolima & Bryozoa & Teichichnus & Coprolites \\
\hline Palaeoneilo brevisstrom & Fenestella trepostome & & 'Spirorbis' \\
\hline Palaeoneilo laevirostrum & Rhabdomason & & stromatolites \\
\hline Palaeoneilo luiniformis & dermata & TYPE 3 ASSEMBLAGE & 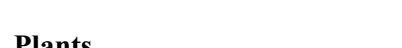 \\
\hline Palaeoneilo mansoni & $\begin{array}{l}\text { EchInoaermata } \\
\text { Archaeocidaris }\end{array}$ & Ostracoda & $\begin{array}{l}\text { Plants } \\
\text { spinose megaspores }\end{array}$ \\
\hline Palevoldia maegregori & Crinoid columnals & Carbonita sp. & Sphenopteris affinis \\
\hline Parallelodon & Echinocidaris & Cavellina benniei & Telangium affinae \\
\hline Permopecten sowerbii & Arthropoda & Cavellina taidonensis & \\
\hline Permopecten & Trilobite fragment indet. & Cavellina sp. & \\
\hline Permopectinella & & Geisina arcuata & ENVIRONMENT UNCERTAIN \\
\hline Polenomorpha minor & $\begin{array}{l}\text { Cephalopoda } \\
\text { Bevrichoceratoides }\end{array}$ & palaeocope sp. A & Ostracoda \\
\hline Polenomorpha & Goniatite fragments indet. & palaeocope sp. B & Acratia sp. A \\
\hline Polidevica attenuata & Stroboceras & Paraparchites circularis $\mathrm{n}$. sp. & Glyptolichvinella spiralis \\
\hline Punctospyrifa & Nautiloid indent. & Shemonaella siveteri $\mathrm{n} . \mathrm{sp}$. & palaeocope sp. D \\
\hline Sanguinolites clavatus & Orthocones indent. & Shemonaella ornata $\mathrm{n} . \mathrm{sp}$. & \\
\hline Sanguinolites costellaters & Others & Silenites sp. A & \\
\hline Sanguinolites variabiles & Conularid & Bivalvia & \\
\hline Sanguinolites & Paraconularia & Curvirimula & \\
\hline Schizodus & Serpulites carbonius & Curvirimula cf. scotica & \\
\hline Sedgwickia gigantea & Serpulites & Naiadites crassus & \\
\hline Sedgwickia & Ichnolites & Naiadites obesus & \\
\hline Solenomorpha cf. minor & Chondrites & Naiadites & \\
\hline Solenomorpha & & Vertebrata & \\
\hline Streblochondria elliptica & & fish fragments indet. & \\
\hline Streblochondria & & Others & \\
\hline Streblopteria ornata & & coprolites & \\
\hline Wilkingia maxima & & 'Spirorbis' & \\
\hline Wilkingia & & stromatolites & \\
\hline Porifera & & & \\
\hline Hyalostelina & & & \\
\hline
\end{tabular}

Three ostracod species do not occur with other fauna and therefore have an uncertain ecology.

In the Anstruther Formation Randerston section (Fig. 6c-f) an algal limestone with both stromatolitic (Fig. 6c) and oncoidal forms (Fig. 6d, f) contains the earliest record of Carbonita from the Midland Valley. Some of the oncoids incorporate pisoliths and ostracods in their centres. The ostracod assemblage is composed of $30 \%$ carapaces, whole single valves, and a range of adults and juveniles, representing a thanatocoenosis (Fig. 6f). In other areas there are abundant single valves, densely packed together, 
Table 5. Faunal associations of common Strathclyde Group non-marine macrofossils and ostracods

\begin{tabular}{|c|c|c|c|c|c|c|c|c|c|c|c|c|c|c|c|c|c|c|}
\hline \multirow{2}{*}{$\begin{array}{l}\text { Assemblage } \\
\\
\text { Types 2-4 fauna of interest }\end{array}$} & \multicolumn{2}{|c|}{ Type 1} & \multicolumn{5}{|c|}{ Type 2} & \multicolumn{5}{|c|}{ Type 3} & \multicolumn{6}{|c|}{ Type 4} \\
\hline & 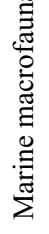 & 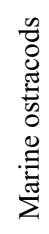 & 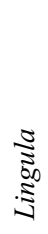 & 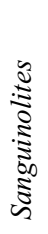 & 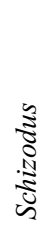 & $\frac{\stackrel{\Xi}{\Xi}}{\stackrel{\Xi}{\Xi}}$ & 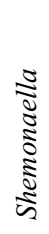 & 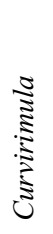 & 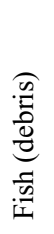 & 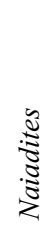 & 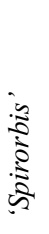 & 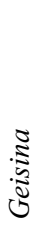 & 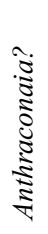 & 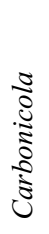 & 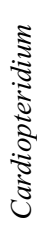 & 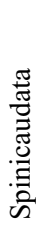 & 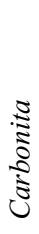 & 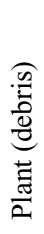 \\
\hline \multicolumn{19}{|l|}{ Macrofossils } \\
\hline Anthraconaia? & 0 & 0 & 0 & 0 & 0 & 0 & 0 & 0 & 1 & 2 & 0 & 0 & $\mathrm{X}$ & 0 & 0 & 0 & 0 & 0 \\
\hline Carbonicola & 1 & 0 & 0 & 0 & 1 & 0 & 0 & 0 & 2 & 0 & 0 & 0 & 0 & $\mathrm{X}$ & 0 & 0 & 0 & 5 \\
\hline Cardiopteridium & 0 & 0 & 0 & 0 & 0 & 0 & 0 & 0 & 0 & 1 & 0 & 0 & 0 & 0 & $\mathrm{X}$ & 0 & 0 & 1 \\
\hline Curvirimula & 1 & 0 & 0 & 0 & 0 & 0 & 0 & $\mathrm{X}$ & 17 & 0 & 18 & 0 & 0 & 0 & 0 & 0 & 0 & 21 \\
\hline Fish (indet.) & 3 & 0 & 7 & 0 & 3 & 0 & 0 & 16 & X & 15 & 20 & 0 & 1 & 2 & 0 & 4 & 0 & 33 \\
\hline Lingula & 39 & 0 & $\mathrm{X}$ & 2 & 6 & 0 & 0 & 0 & 9 & 13 & 0 & 0 & 0 & 0 & 0 & 2 & 0 & 2 \\
\hline Myalina & 3 & 0 & 1 & 0 & 0 & 0 & 0 & 0 & 0 & 0 & 0 & 0 & 0 & 0 & 0 & 0 & 0 & 0 \\
\hline Naiadites & 6 & 0 & 14 & 0 & 5 & 0 & 0 & 0 & 12 & $\mathrm{X}$ & 12 & 0 & 1 & 0 & 1 & 5 & 0 & 25 \\
\hline Sanguinolites & 22 & 0 & 2 & $\mathrm{X}$ & 2 & 0 & 0 & 0 & 0 & 0 & 1 & 0 & 0 & 0 & 0 & 0 & 0 & 1 \\
\hline Schizodus & 15 & 0 & 6 & 1 & $X$ & 0 & 0 & 0 & 3 & 4 & 2 & 0 & 0 & 1 & 0 & 0 & 0 & 3 \\
\hline Spinicaudata & 0 & 0 & 0 & 0 & 0 & 0 & 0 & 0 & 4 & 6 & 0 & 0 & 0 & 0 & 0 & $\mathrm{X}$ & 0 & 11 \\
\hline 'Spirorbis' & 3 & 0 & 0 & 1 & 2 & 0 & 0 & 17 & 21 & 12 & $\mathrm{X}$ & 0 & 0 & 0 & 0 & 0 & 0 & 11 \\
\hline \multicolumn{19}{|l|}{ Ostracods } \\
\hline Carbonita & 0 & 0 & 1 & 0 & 1 & 3 & 1 & 1 & 3 & 11 & 4 & 7 & 0 & 0 & 0 & 0 & $\mathrm{X}$ & 3 \\
\hline Cavellina & 16 & 12 & 0 & 1 & 0 & $\mathrm{X}$ & 14 & 1 & 3 & 15 & 1 & 1 & 0 & 0 & 0 & 1 & 2 & 3 \\
\hline Geisina & 2 & 1 & 1 & 0 & 0 & 2 & 2 & 0 & 1 & 10 & 0 & $\mathrm{X}$ & 0 & 0 & 0 & 0 & 0 & 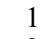 \\
\hline Shemonaella & 21 & 6 & 3 & 2 & 0 & 16 & $\mathrm{X}$ & 9 & 6 & 22 & 4 & 2 & 0 & 0 & 0 & 1 & 1 & 2 \\
\hline
\end{tabular}

Numbers represent the frequency with which the fauna occur in the same assemblage. An X refers to where the same fauna crosses, for example the association of Cavellina with itself. Marine macrofauna include groups such as brachiopods, bryozoa and gastropods, as defined for the Midland Valley of Scotland by Wilson (1989), and in this study as a Type 1 Assemblage. For ostracods, the occurrence data are compiled from the single or often multiple species present for that genus.

representing a taphocoenosis. Overall, the ostracod taphonomy in most algal limestone beds suggests only some limited localized transport.

Pisolithic limestones are the most common in the Anstruther Formation and can contain 'Spirorbis', fish (debris), ostracods, rare Lingula, rare Myalina and abundant plant debris. In the Kingsbarns section a layer with irregular-shaped pisoliths (some of which contain ostracods in the centre) is overlain by siltstone packed with wood debris, including logs up to $4 \mathrm{~m}$ in length (Fig. 6g, h). Poorly preserved ostracods are present in both layers, with single valves composing $95 \%$ of the assemblage.

\section{Ecological interpretation of the Strathclyde Group macrofauna and ostracods}

The interpretation of the ecology of the ostracods is based on macrofauna-ostracod or ostracod faunal associations, with reference to known Mississippian ostracod distribution patterns (Tables 2, 4; Fig. 7). Palaeoenvironments are interpreted based on faunal and sedimentological evidence (Fig. 8).

\section{5.a. Type 1 Assemblage: marine}

These fossil groups have been determined in the MVS as marine (Wilson, 1989). Chondrites is a Palaeozoic marine ichnogenus (Buatois et al. 2005). Most pelagic Type 1 Assemblage fossils are fragmented, while wellpreserved benthic shelf faunas are the richest, and contain the most abundant fossils.
Twelve ostracod species from this assemblage are considered marine (Fig. 7). Of these, Acutiangulata sp. A, Bairdia submucronata, Healdia cf. cuneata, Hollinella (Keslingella) radiata, palaeocope sp. C and Polycope elegans n. sp. are considered to be stenohaline, as they are only associated with marine macrofossils. Bairdia is abundant in Mississippian marine assemblages (Bless, 1983; Bless, Streel \& Becker, 1988), as are Healdia and Hollinella (Přibyl, 1960; Olempska, 1993; Athersuch et al. 2009). Acutiangulata is known for its possible brackish-water tolerance, in association with Shemonaella, Cavellina and 'Spirorbis' (Athersuch et al. 2009; Robinson, 1978). Polycope elegans n. sp. is associated with marine macrofossils in a thanatocoenosis. Polycopids are supposed nektobenthic ostracods (Horne, 2003) and are reported as marine in the Mississippian (Dewey \& Fåhraeus, 1987).

Facies 1 sediments are interpreted as near-shore, shallow marine deposits. Metres-thick successions of mudstones (containing articulated orthocones), representing fairly prolonged marine conditions, occur in the Pathhead Formation (Fig. 8), but are rare. Frequent short-lived marine transgressions are represented by thin marine mudstones overlain by coarsening-upwards successions. The low diversity of the marine ostracod fauna suggests short-lived open marine conditions. Only six species are interpreted as stenohaline and other common Mississippian marine ostracods such as Kirkbya and Amphissites (Coen, Michiels \& Parisse, 1988; Olempska, 1993) are absent. The tens of metres thick sandstone units of Facies 3a, with 


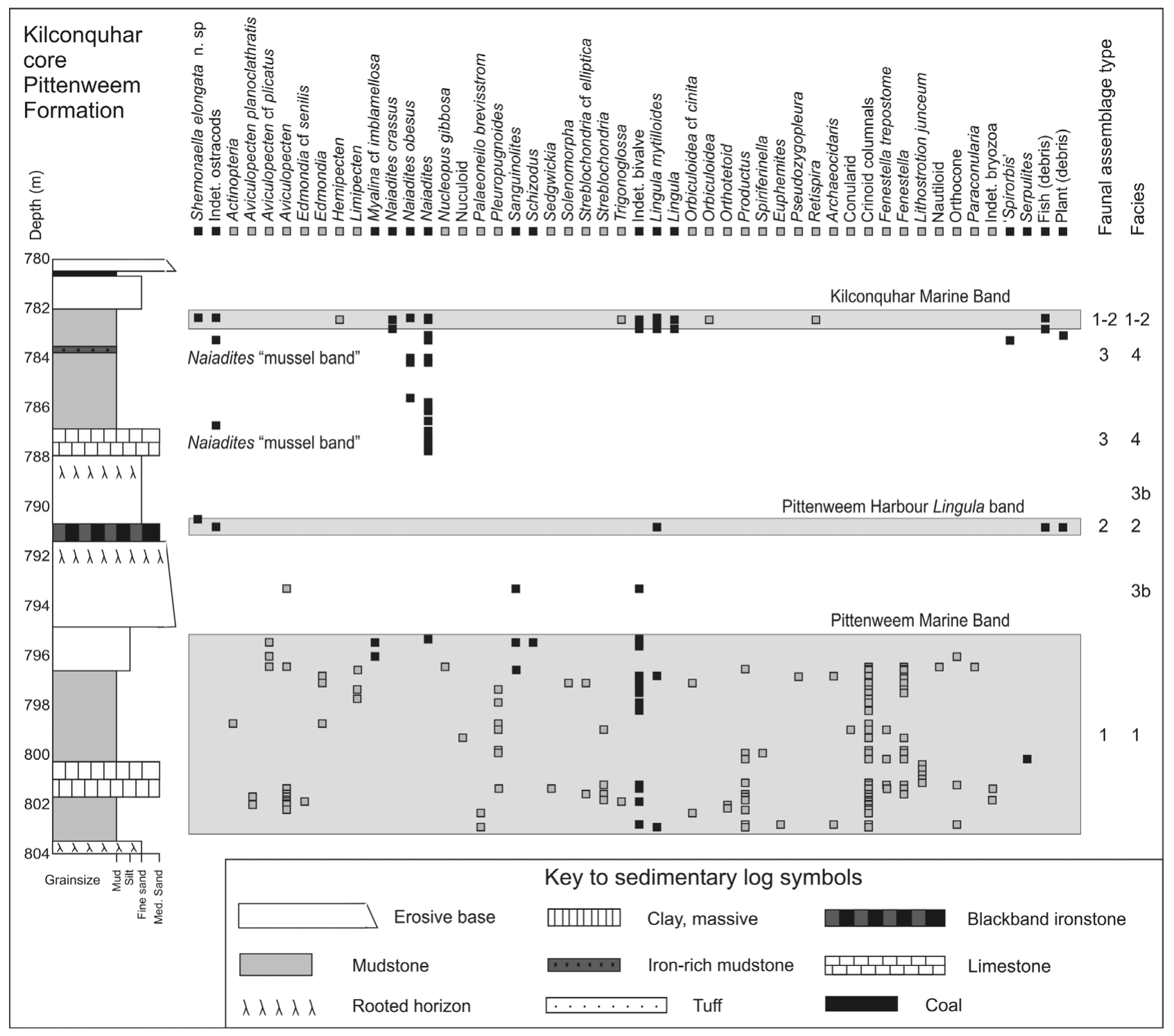

Figure 3. Sedimentary log and fauna of part of the Pittenweem Formation. Type 1 Assemblage elements are represented by a grey colour square and Type 2 to 4 assemblage elements by a black square, at the height in the core at which they occur. The sedimentary $\log$ key covers Figures 3-5.

convolute-bedding and channel forms indicate proximal deltaic mouth bar deposition, with a rare marine macrofauna incorporated at the delta front.

\section{5.b. Type 2 Assemblage: marginal marine}

The lower-diversity Type 2 Assemblage is interpreted as marginal marine. Lingula squamiformis from the Mississippian of the MVS has been interpreted as a brackish species (Ferguson, 1963). Here, Schizodus, Sanguinolites and Lingula have similar faunal associations and are interpreted as marginal marine. Myalina is recorded as a common freshwater bivalve by Ferguson (1962), but in the present study its associations (Table 5) determine it as marginal marine, albeit based only on low numbers of specimens.

Six species from the Type 2 Assemblage, that occur in a range of marine, marginal marine and brackish to freshwater sediments (Fig. 7), are considered as eurytopic or marginal marine. Post-Palaeozoic ostracods of the Suborder Platycopina are exclusively marine (Horne, 2003), but the Mississippian platycopes Cavellina, Geisina and Glyptolichvinella are euryhaline or of uncertain ecology. At a generic level, ostracod-macrofaunal associations reveal that Cavellina and Shemonaella have a wide salinity tolerance (Table 5). In particular, the species Cavellina valida and Shemonaella elongata $\mathrm{n}$. sp. are abundant (Table 2) and occur in a wide range of environments (Fig. 7) with many other ostracod species (Table 3) and are considered to be eurytopic. Cavellina is known for its marginal marine to brackish-water tolerance in Carboniferous environments (Robinson, 1978; Williams et al. 2005, 2006). Many Mississippian Shemonaella species are interpreted as marine (for example, Crasquin, 1985; Dewey, 1983), but some are considered as brackish (Tibert \& Scott, 1999). Mississippian species of Paraparchites with dorsal spines occur in association with typically marine genera such as Amphissites and Bairdia (Sohn, 1969). 


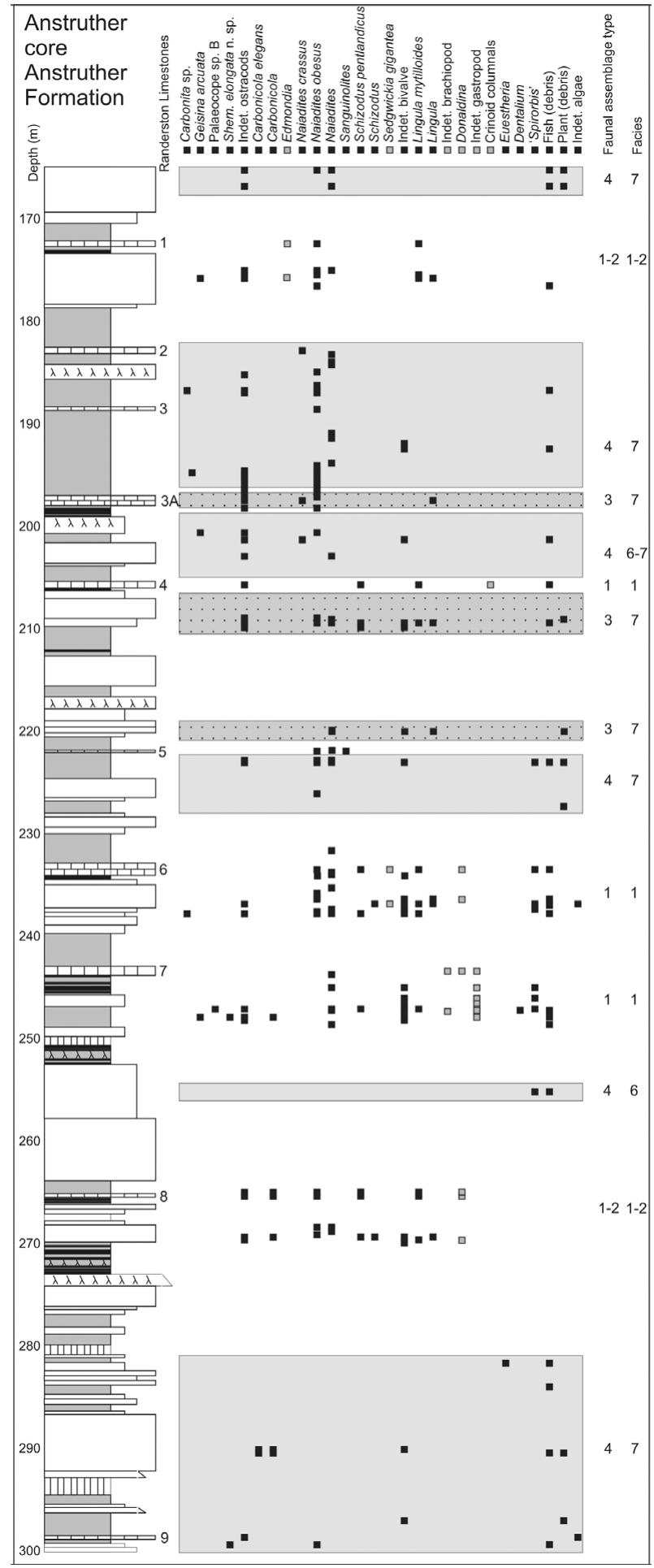

Figure 4. Sedimentary log and fauna of part of the Anstruther core (Randerston Section), Anstruther Formation. Sediments containing Type 3 and 4 assemblages are highlighted with shaded boxes in the background. The Randerston limestones 6 and 7 are typical of those containing a Type 1 Assemblage from this formation.

Here, Paraparchites armstrongianus is interpreted as marginal marine (Fig. 7, Table 5). Marginal marine environments include lagoons, embayments or estuaries associated with lower salinities (Fig. 8). Many ostracods are eurytopic and these environments may have provided a pathway for marine to non-marine transitions.

\section{5.c. Type 3 Assemblage: brackish-freshwater}

Palaeozoic spirorbids are reported from freshwater, brackish, marine and hypersaline environments (Taylor \& Vinn, 2006; Wilson, 1989). Here, the faunal associations of 'Spirorbis' suggest that it is brackish-water tolerant. Curvirimula, Naiadites, fish and 'Spirorbis' are interpreted to have a brackish to freshwater tolerance.

Four ostracod species are interpreted as brackish to freshwater tolerant. Geisina arcuata is mostly associated with brackish to freshwater (Type 3) macrofossils (Table 5), and this is a common environmental interpretation for this species in the Mississippian (Pollard, 1966, 1969; Anderson, 1970; Bless \& Pollard, 1973; Bless, Streel \& Becker, 1988). Paraparchites circularis $\mathrm{n}$. sp. occurs in great abundance in blackband ironstones, which may represent opportunistic reproduction in quickly colonizing this plant-rich environment. Carboniferous species of Paraparchites have been recorded from environments interpreted as marine (Dewey, 1988), non-marine (Kummerow, 1953; Williams et al. 2005) and hypersaline (Dewey, 1983, 1987, 1988; Williams et al. 2005, 2006). The associations of Shemonaella ornata n. sp. (ostracods, Naiadites, fish and plant debris) indicate more brackish-water tolerance than S. elongata $\mathrm{n}$. sp. Despite its faunal associations here, Mississippian Silenites has been recorded from marine sediments (Crasquin, 1985).

Naiadites is commonly associated with brackish macrofauna such as Curvirimula and 'Spirorbis' or occurs as a monospecific assemblage in Facies 4 sediments. Its rare occurrence in association with marine faunas may be owing to post-mortem transport. Naiadites mussel bands have undergone postdepositional transport by currents and wave action, as is seen in shallow marine bivalve and oyster coquinas (Wakefield, 1995). As the exact palaeoenvironmental conditions of Naiadites and other macrofauna are not known, there is uncertainty regarding a brackish or a freshwater interpretation.

\section{5.d. Type 4 Assemblage: freshwater}

Anthraconaia, Carbonicola and Cardiopteridium are interpreted as freshwater bivalves (Bennison, 1960, 1961). Anthraconaia and Carbonicola are commonly associated with Naiadites in Pennsylvanian freshwater Coal Measures (for example, Jenkins, 1960; Hartley, 1993; Brand, 1996; Eagar \& Belt, 2003). Anthraconaia, Carbonicola, Curvirimula and Naiadites occur in brackish (Ballèvre \& Lardeux, 2005) or lacustrine Mississippian sediments (Guirdham et al. 2003) and freshwater Pennsylvanian sediments (Brand, 1994; Anderson et al. 1999; Falcon-Lang, 2005; Falcon-Lang et al. 2006). 


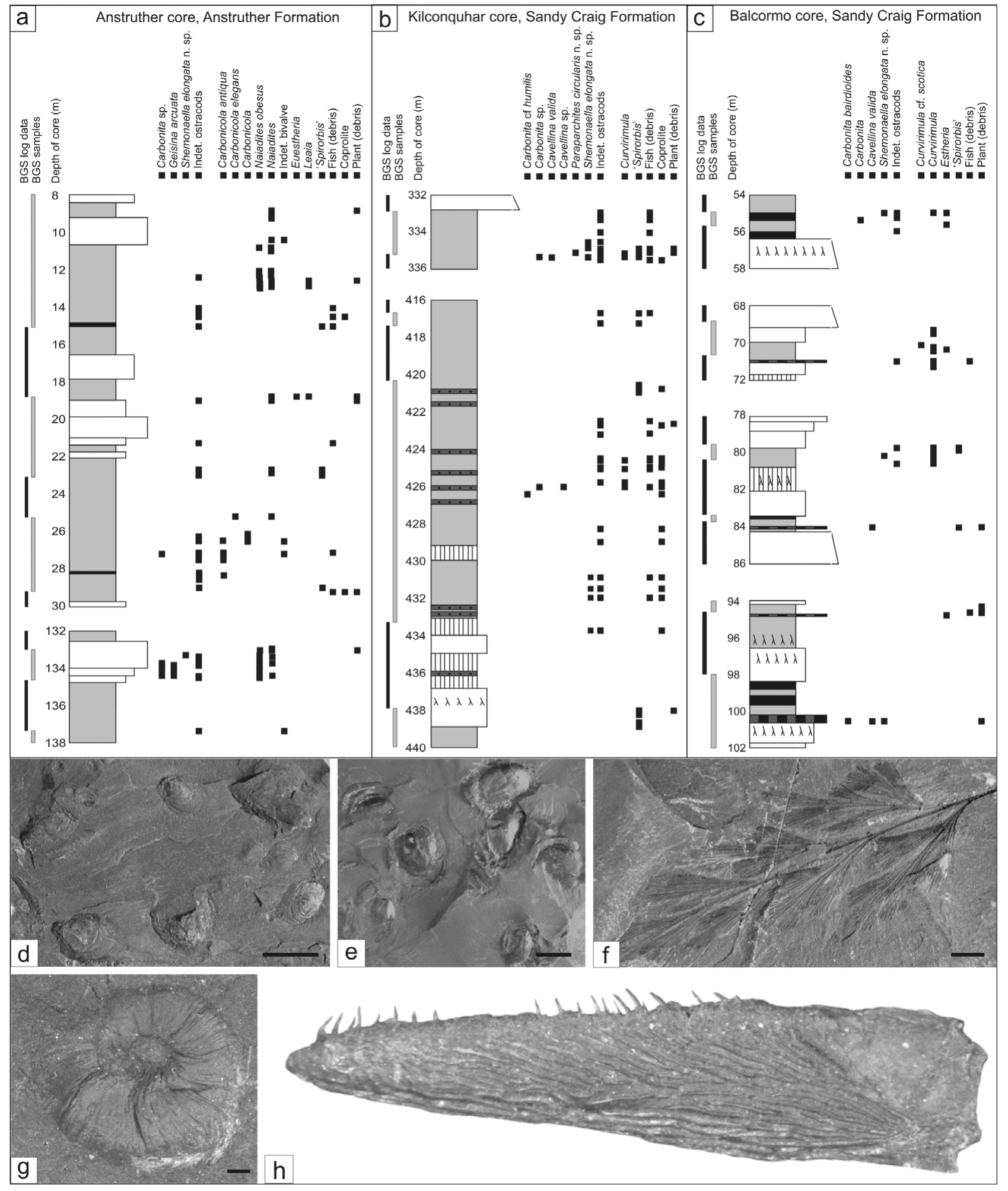

Figure 5. Sedimentary logs of Facies 5 and 6 containing ostracods $(a-c)$ and common Type 3 and 4 assemblage macrofossils (d-h). Mudstones contain the most fossils. (d) Curvirimula cf. scotica, pyritized, GSE 15376. (e) Naiadites obesus, GSE 15378. (f) Telangium affinae, GSE 15380. (g) 'Spirorbis', GSE 15379. (h) Fish jaw plate with teeth, $10.5 \mathrm{~mm}$ in length, GSE 15382. Light photographs, scale bars $5 \mathrm{~mm}(\mathrm{~d}, \mathrm{f})$ and $0.2 \mathrm{~mm}(\mathrm{~g})$. Specimens are stored in the palaeontology collection at the BGS, Edinburgh.

Extant Spinicaudata typically live in freshwater, but can tolerate salinities up to $6 \%$ o $\mathrm{NaCl}$. Late Palaeozoic Spinicaudata are found in a range of freshwater to brackish coastal plain sediments (Knox \& Gordon, 1999; Jones \& Chen, 2000; Park \& Gierlowski-Kordesch, 2007). Some brackish water records are interpreted as a taphocoenosis (for example Webb, 1979), and Late Palaeozoic spinicaudants mostly occur in freshwater environments, including coals and lake sediments (Orr \& Briggs, 1999; Vannier, Thiery \& Racheboeuf, 2003; Hmich et al. 2006). 
The association of possible actinopterygian and sarcopterygian fish debris in Type 3 and 4 assemblages is consistent with a brackish to freshwater ecology. Freshwater actinopterygians and sarcopterygians are common in the Late Palaeozoic (for example, Daeschler, 2000; Trewin \& Davidson, 1996; Turner, Kemp \& Warren, 1999). In other contemporaneous MVS sedimentary rocks, fish occur in a range of water bodies, from deep-lagoonal (the Wardie Shales) to a semi-permanent lake on a coastal plain (the Foulden Beds; see Dineley \& Metcalf, 1999).

Species of Carbonita are mostly associated with brackish to freshwater macrofossils (Table 5) and, importantly, only species of Carbonita occur exclusively in sediments interpreted as freshwater (Fig. 7): Carbonita bairdioides and Carbonita cf. inflata occur in blackband ironstones; Carbonita cf. fabulina and Carbonita cf. humilis in siltstones-mudstones associated with plant and fish debris. Carbonita is described from Mississippian brackish water sediments (Pollard, 1985; Sohn, 1985; Tibert \& Scott, 1999). Vannier, Thiery \& Racheboeuf (2003) first document unambiguous freshwater Carbonita from Pennsylvanian sediments deposited in an intramontane temporary pond.

The cross-bedded sandstones with sigmoidal structures of Facies $3 \mathrm{~b}$ are interpreted as meandering fluvial channels. The low-diversity ichnofauna typify brackish to estuarine conditions (Buatois et al. 2005), consistent with a macrofauna of Naiadites, fish and plants. Overbank deposits contain Stigmaria roots and desiccation cracks. The mouth bar and alluvial environments are important components of the environment, but lack ostracods (Fig. 8). Facies 5 mudstones containing Type 3-4 assemblages and abundant plant debris are interpreted as freshwater inland lake or temporary pond deposits. These are present in all except the Pittenweem Formation (Fig. 8). Temporary pools or shallow lakes are a common habitat for Spinicaudata (Vannier, Thiery \& Racheboeuf, 2003) and fish (Dineley \& Metcalf, $1999)$ in the Carboniferous. The ostracod-bearing pisolithic plant-rich algal limestone is interpreted to have formed in a shallow carbonate-rich temporary pond or lake where pisoliths formed. The original ostracod ecology is uncertain owing to transport; the ostracods may have originated in a nearby freshwater swamp where wood accumulated, and were later transported to the site of deposition.

The blackband ironstones of Facies 6 represent a key depositional environment for freshwater ostracods. The macrofaunal content of these sediments favours a freshwater interpretation. Blackband ironstones are common in the Pennsylvanian Coal Measures, generally associated with upper delta-plains to alluvial floodplains and coastal plain swamps with small lakes (Boardman, 1989). The Strathclyde Group depositional setting is interpreted as a swampy wetland where plant debris had time to accumulate, creating the black laminae alternating with iron-rich mudstone-siltstone deposited in shallow water stream-fed pools. Fine grain size suggests still-water deposition and the laminae indicate shallow to fluctuating water levels and the periodic accumulation of plant debris.

The 'seat-earths' present below coal beds are interpreted as exposure surfaces on a well-drained floodplain, where vegetation had time to develop. Most of these horizons are thin, and are interpreted as relatively brief periods of sub-aerial exposure. The three thicker, extensively rooted horizons are interpreted as palaeosols that developed over a longer time period, and would be classified as a spodosol (sandy forest soil; Retallack, 2001). These units are important for interpreting terrestrial conditions.

The non-marine limestones/dolostones (Facies 7) and associated sedimentary rocks of the Anstruther Formation are a key environment for early nonmarine ostracods (Fig. 8). Within these lake-deltaic cycles, occasional marine transgressions occurred, but the predominance of Type 3 and 4 assemblages indicates that brackish to freshwater salinity conditions were the most prevalent. Freshwater conditions were unstable, seen in the variation of stromatolitic to oncoidal algal forms (Logan, Rezak \& Ginsburg, 1964) and the presence of desiccation cracks, although the periods of exposure were short-lived enough not to result in pedogenesis (cf. MacNeil \& Jones, 2006). Carboniferous freshwater algal limestones have been reported from the MVS (Guirdham et al. 2003), France (Freyet, Broutin \& Durand, 2000) and Illinois (Scott, 1944). In the Pennsylvanian of Illinois stromatolitic limestones contain abundant indeterminate ostracods and 'Spirorbis', interpreted to have lived in a shallow water lake (Scott, 1944). Oncoidal-type grains are more problematic, as they have been described from a range of marine to non-marine settings (Davaud \& Girardclos, 2001; Peryt, 1983). The algal species of the present study cannot be determined, but despite this, we know that ostracods lived in association with these algal forms and that the environment was probably freshwater.

\section{5.e. Uncertain environment}

When there is only one ostracod specimen for a particular species, with few or no associated faunas, the palaeoecology is uncertain, as in the case of Acratia sp. A, Glyptolichvinella spiralis and palaeocope sp. D. Acratia is reported as marine (Olempska, 1993), and Glyptolichvinella as marginal marine to brackish (Williams et al. 2005, 2006).

\section{The ostracod radiation into non-marine environments}

The success of the initial colonization of non-marine water bodies by ostracods was probably dependent on a number of factors, including intrinsic adaptations of ostracod species to lower salinities; extrinsic mechanisms to drive non-marine colonization, such as changing sea-levels; and a favourable aqueous 

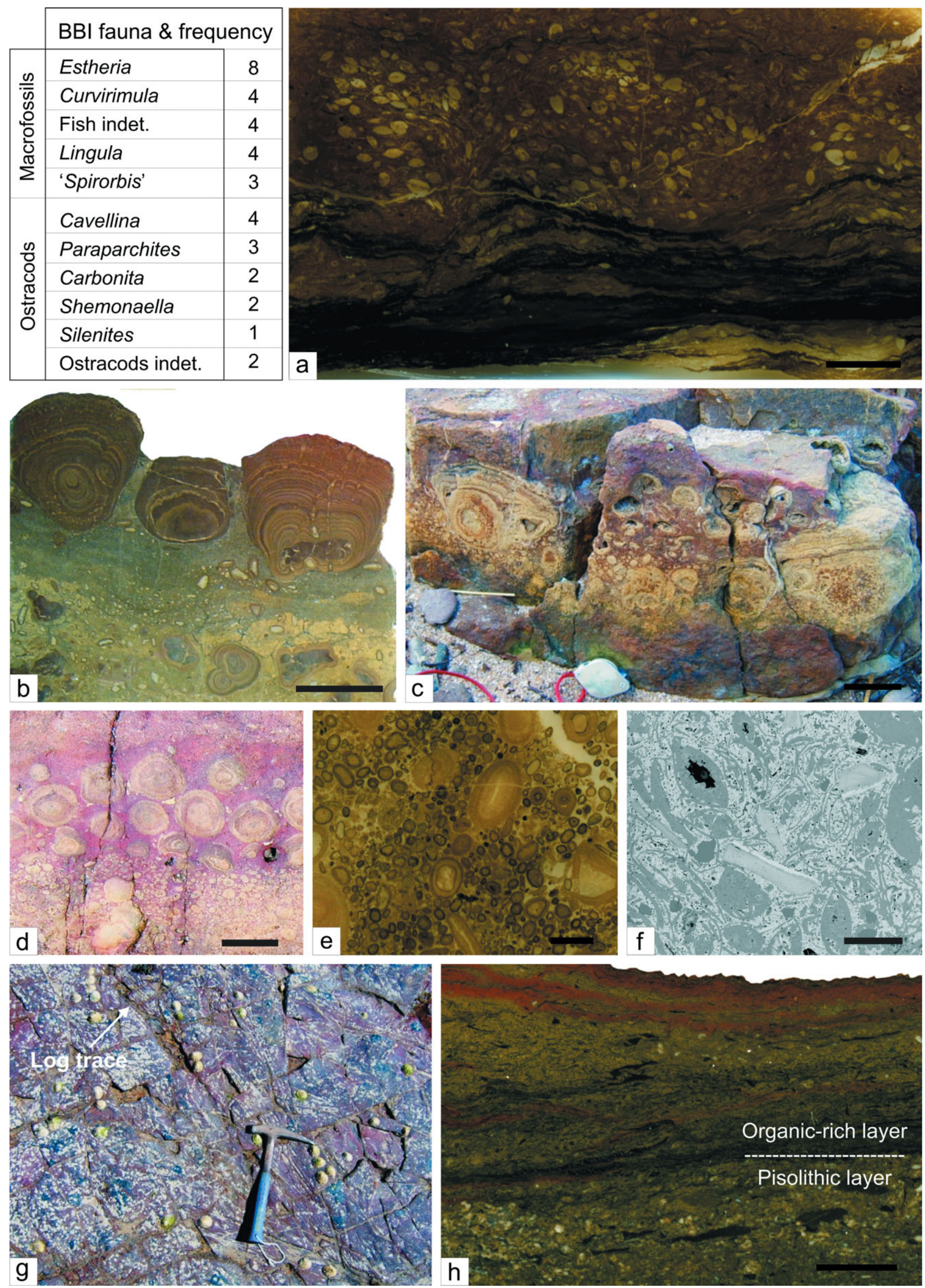

Figure 6. (Colour online) Facies 6 (blackband ironstone; BBI) and Facies 7 (algal limestones) containing ostracods. Table of fauna occurring within BBIs, the most common fauna is Spinicaudata. (a) Polished thin-section (PTS) of a BBI from the Sandy Craig Formation, containing abundant Paraparchites circularis n. sp., MPK 14009. (b) Well-formed stromatolites, Pittenweem Formation, 
continental environment to foster ostracods in this new environment.

\section{6.a. Intrinsic adaptations of non-marine ostracods}

Of the brackish to freshwater ostracods from this study, their origin and affinity to known living freshwater ostracods is poorly resolved, particularly because all of these Carboniferous genera (Carbonita, Cavellina, Geisina, Paraparchites, Shemonaella and Silenites) became extinct by the end-Permian (Moore, 1961). The Carbonitoidea have no extant relatives or preserved soft parts for comparison. The origins of the Carbonitoidea are unknown; hypotheses link them to the marine Healdioidea (Retrum \& Kaesler, 2005), Darwinulocopina or marine Sigilloidea (Horne, 2003). Retrum \& Kaesler (2005) noted that the muscle scar pattern of Permian freshwater Carbonita is more like that of the Healdioidea than the Cytheroidea or Cypridoidea. While the Carbonitoidea have been compared to living podocopes such as Cypridopsis (Neale, 1984), the evidence for true cypridoideans in the Carboniferous is debated: some argue for a Late Palaeozoic origin (Lethiers \& Damotte, 1993; Swain, 1976); others place the origin of the Cypridoidea in the Mesozoic (Horne 2003; Tibert et al. 2003; Whatley \& Ballent, 1996).

Despite the problems of relating Carboniferous ostracods to living species, it is clear that important and fundamental physiological changes would be needed for ostracods to adapt to reduced salinities. Of primary importance are osmoregulation and reproductive changes, along with modifications in lifestyle. For the individual animal to survive it would have to regulate the salt intake and output. Osmoregulation takes place by gaseous exchange through the integumental circulatory system in the inner lamella (Aladin \& Potts, 1996; Vannier \& Abe, 1995). Some living ostracods such as Cyprideis torosa are very successful at this and can survive in salinities of $1-40 \% \circ \mathrm{NaCl}$ (Keyser, 2005; Van Harten, 2000). Other ostracods, for example Cavellina species, which are interpreted as having been eurytopic herein, may have been as adaptable as Cyprideis torosa, although there are no visible signs to indicate how they dealt with osmoregulation, such as variation in carapace ornamentation. For Palaeozoic fossils with no preserved soft parts, inferences have to be made from the carapace. For paraparchitoidean ostracods, the strategy of having a large, thick carapace and an associated integumental circulatory system may have been beneficial in dealing with osmotic pressures caused by changing salinities. This has been suggested for the Leperditicopida (Vannier \& Abe, 1995; Vannier, Wang \& Coen, 2001), which have a similarly proportioned carapace and are also adapted to non-marine environments, although it is not an exclusively freshwater adaptation.

Reproductive strategy to survive non-marine environments focuses on the ability to reproduce rapidly in often short-lived water bodies (r-strategy) and the development of desiccation-resistant eggs. Evidence for the first of these strategies comes from the hypothesis that Carboniferous paraparchitoideans may have used progenesis and parthenogenetic reproductive strategies to reproduce rapidly in hypersaline conditions (Dewey, 1987). The production of desiccation and transport-resistant resting eggs has been proposed for the Cypridoidea, which had a successful non-marine diversification the Early Cretaceous (Whatley, 1990a,b; Lethiers \& Damotte, 1993). This adaptation would enable the survival of ostracods that lived in ephemeral water bodies such as seasonal freshwater lakes, like the resting eggs produced by the Spinicaudata of the Carboniferous Monteceau Lagerstätte, which are associated with Carbonita (Vannier, Thiery \& Racheboeuf, 2003). Although Carbonita is fairly diverse in the Carboniferous (Anderson, 1970 identifies 17 species), no ostracod resting eggs have ever been found.

Possible modifications to lifestyle, such as feeding and locomotion changes, are more speculative. In the Pennsylvanian and Permian, Carbonita was better adapted than Geisina to different sedimentary niches, and it was more taxonomically diverse (Bless \& Pollard, 1973). It has been proposed that Carbonita may have been a deposit feeder like the Recent Cypridopsis, and was perhaps therefore more adaptable than Geisina, which may have been a filter feeder like modern platycopes (Neale, 1984; Pollard, 1966). In terms of locomotion, some have argued the adaptation to a swimming mode of life was a key part to the success of the cypridoideans in colonizing nonmarine environments in the mid-Mesozoic (along with the adaptation of desiccation-resistant eggs and parthenogenesis: Whatley, 1990a,b, 1992), and it is possible that this was also adopted by Carboniferous Carbonitidae.

\section{6.b. Mechanisms for non-marine radiation}

Like many aquatic animals, ostracods appear to have made the transition from marine to non-marine waters in a coastal setting. For example, early Mississippian Carbonita is associated with near-shore marine to low-salinity coastal ponds (Tibert \& Scott, 1999).

SE 8699. (c-f) Images of the Randerston limestone 9, Anstruther Formation. (c) Vertically stacked hemispheroids and oncoids, field photograph. (d) Size-separated layers of oncoids and pisoliths, field photograph. (e) Abundant ooliths; the concentric laminae are a few microns in thickness, MPK 14004, PTS. (f) Abundant ostracod carapaces, single valves and fish teeth, MPK 14000, PTS, BSEM image. (g, h) Pisolithic plant-rich limestone, Kingsbarns section. (g) Top surface of the limestone bed with numerous log traces (see arrow), field photograph. (h) Cut section through the limestone bed, field sample 19. Scale bars $5 \mathrm{~mm}(\mathrm{a}), 2 \mathrm{~cm}(\mathrm{~b}-\mathrm{d}), 500 \mu \mathrm{m}(\mathrm{e}, \mathrm{f})$ and $10 \mathrm{~mm}(\mathrm{~h})$. 


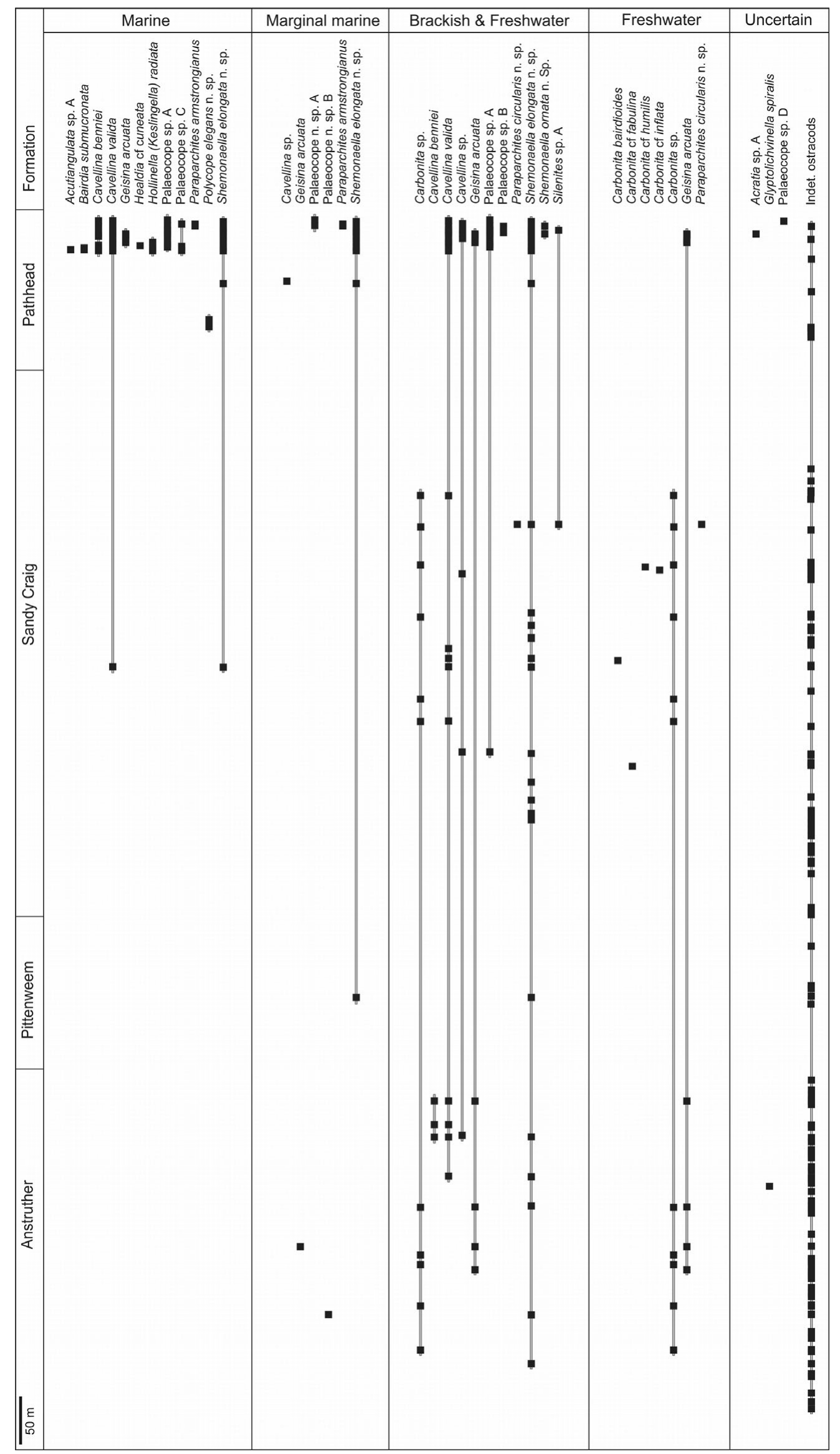

Figure 7. Stratigraphic range and palaeoenvironments of the Strathclyde Group ostracods. Cavellina valida, Geisina arcuata, palaeocope sp. A and Shemonaella elongata $\mathrm{n}$. sp. are the most long ranging. 


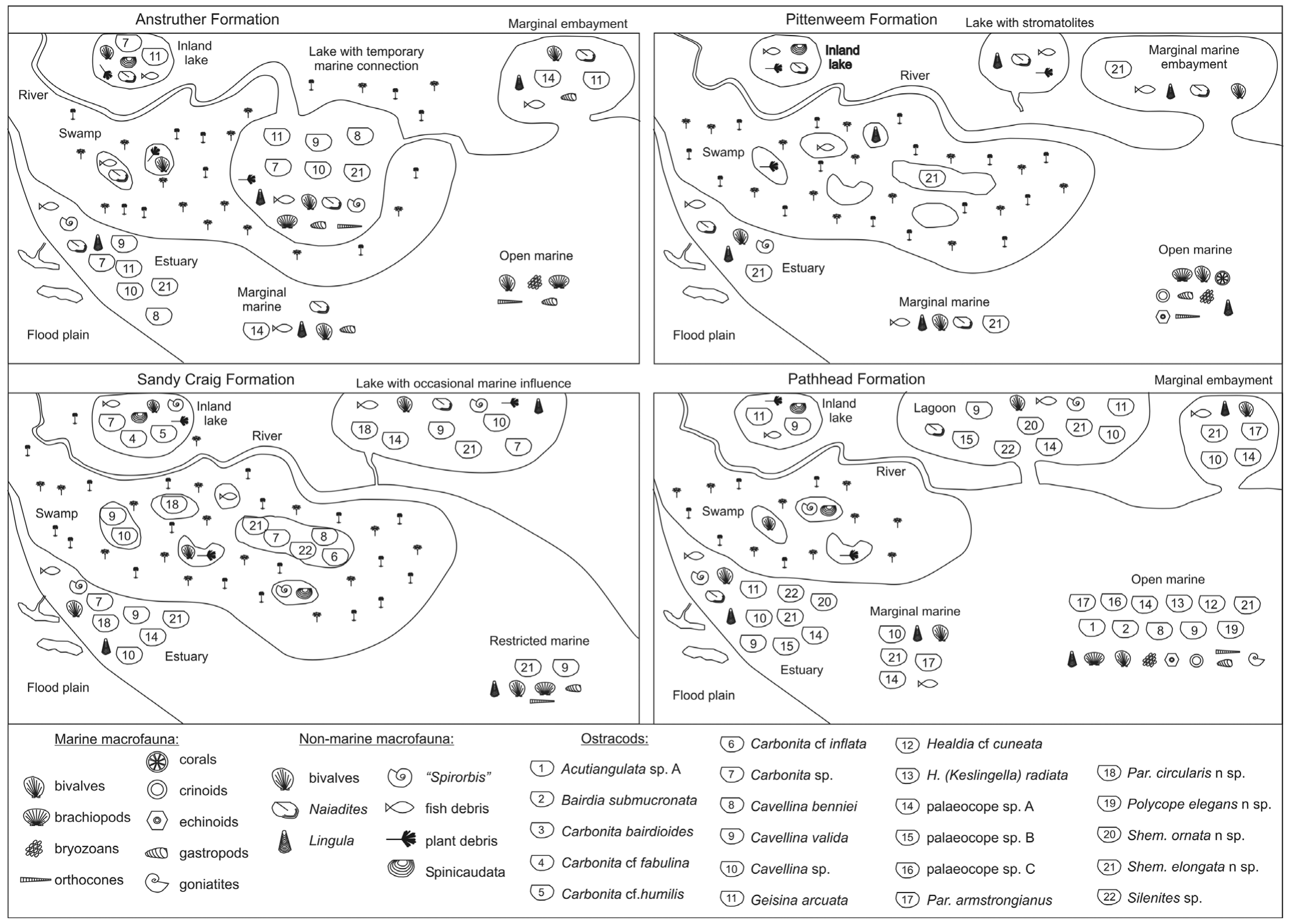

Figure 8. Palaeoenvironmental model of the ecological range of ostracods for the Anstruther to Pathhead formations. The environmental range of each ostracod species is plotted using the data from Tables 2 and 4, and does not include ostracods that have an indeterminate taxonomy or ecology. Plants are representations of a Carboniferous lycopsid and of Valmeyerodendron. Abbreviations used for ostracod species in the key: H. - Hollinella; Par. - Paraparchites; Shem. - Shemonaella. In the Anstruther Formation blackband ironstones are not present and coals are uncommon, so swampy conditions are minimized in the model. The presence of only Shemonaella elongata $\mathrm{n}$. sp. ostracods in the Pittenweem Formation is due to poor preservation. The Sandy Craig Formation is dominated by non-marine conditions. Stromatolitic limestones are absent in the Pathhead Formation, so a near-shore lake is excluded from the model. 
In the Pennsylvanian, Carbonita is also found in coastal environments, such as brackish waters and poorly drained coastal plain sediments (Falcon-Lang et al. 2006; Tibert \& Dewey, 2006). This 'estuary effect' of non-marine colonization (Gray, 1988; Park \& Gierlowski-Kordesch, 2007) is important as it allowed invertebrates to exploit marine transgressions and varying salinity to inhabit otherwise insupportable non-marine environments. In the Carboniferous of the MVS, the stratigraphical pattern of marine bands shows that there were fairly frequent but mostly short-lived marine transgressions and glacio-eustatic cycles from the late Viséan onwards (Kassi et al. 2004).

Following this estuarine or marine transgression pathway, it is possible that ostracods undertook 'active' and 'passive' (see Gray, 1988) non-marine colonization. Active invasion from the sea by euryhaline ostracods may have occurred at times of high sea-level. Marine species may have developed an osmoregulatory adaptation, to allow them to survive in rapidly changing salinities such as in an estuary. The 'incentive' for this costly physiological adaptation would have been access to a rich food source and relatively sparsely populated new habitat. Over time such ostracod species would become more tolerant of freshwater conditions and able to survive in freshwater bodies such as lakes. Evidence for this long-term ecological adaptation is suggested in the fossil record, with the first cases of ostracodlike animals close to land at delta-front settings in the early Cambrian (Loughlin \& Hillier, 2010; Siveter \& Williams, 1995), putative marginal marine to brackish ostracods from the Silurian (for example Floyd \& Williams, 2003), brackish ostracods in the Devonian (for example Bless, 1983) and finally successful freshwater colonization in the Carboniferous (for example Vannier, Thiery \& Racheboeuf, 2003).

Passive invasion may have occurred owing to fluctuating sea-levels and the restriction of ostracods to isolated habitats, for example in subtidal areas that were isolated and freshened when sea-level fell. As mentioned previously, reproductive adaptations such as resting eggs may also have enabled ostracods to exploit temporary coastal plain water bodies. However, the fairly rapid salinity change that would occur in this scenario means that only species that were already preadapted to euryhaline conditions would survive, owing to the pressures of osmoregulation. The 'patchy' fossil record of non-marine ostracods in the Devonian and earlier may be explained by a series of passive invasion events and 'failed' non-marine colonizations. Nonaquatic means of passive invasion have been proposed, such as the transport of ostracods or desiccationresistant ostracod eggs on the body of tetrapods, or blown by humid winds (Lethiers \& Damotte, 1993).

Whether adaptation was active or passive, there may have been evolutionary advantages in moving out of the marine realm. For example, the Late Devonian ocean anoxia (Algeo et al. 1995) may have driven adaptation into new environments. The onset of the Carboniferous glaciation in the Mississippian (Fielding, Frank \& Isbell, 2008; Mii, Grossman \& Yancey, 1999) would have dramatically affected sea-level and destabilized the shallow marine shelf environment. There is evidence in marine invertebrate populations of low levels of origination, extinction and diversity, from the Mississippian/Pennsylvanian boundary (where there was a second order extinction) for the following $50 \mathrm{Ma}$ (into the Permian; Stanley $\&$ Powell, 2003). Changes in the marine environment and ostracod populations may thus have driven some species to invest in non-marine adaptations.

\section{6.c. Early non-marine environments}

The earliest known record of freshwater ostracods is preserved in lacustrine algal limestones in the Anstruther Formation of the MVS, which were colonized by Carbonita sp. Ostracods may have initially colonized this environment owing to passive transport during marine transgression over the lake and remained there as the water freshened. The algae would have provided a suitable food source; a similar adaptation has been proposed for certain leperditicopids associated with stromatolites (see Siveter, 1984; Vannier, Wang \& Coen, 2001; Warshauer \& Smosna, 1977).

Coal seams and blackband ironstones are common in the Strathclyde Group, and are interpreted as wetland swamp deposits. No terrestrial macrofauna were observed (such as the Pennsylvanian land snail Archandon; Hebert \& Calder, 2004), but these wetland freshwater environments are important for ostracods. Carbonita is recorded from blackband ironstones in this study and is even more common in the Pennsylvanian Coal Measures (see, for example, Sohn, 1985). Ostracods may have been fostered in these environments by exploiting the rich plant detritus coming from the land; the increase in the diversity of detritus-feeding epifauna can be linked to the increased abundance of Carboniferous land plants (Buatois et al. 1998).

Were the ostracods associated with coal deposits terrestrial? Genetic studies estimate that terrestrial ostracods may have been present as early as the Ordovician (Newman, 2005). The ostracods in organicrich sediments in the present study are assumed to be fully aquatic, but it is possible that the absence of a fossil record of terrestrial ostracods may be a preservational rather than ecological issue (Horne, 2003), as carapaces are unlikely to be preserved in the acid peat-bog environment of coal deposits. Further studies on coal seams are needed to confirm an ostracod presence in coal deposits and a possible semi-terrestrial lifestyle for Mississippian ostracods.

\section{6.d. Timing and duration of non-marine colonization}

Of the most successful Carboniferous freshwater ostracods, Geisina became extinct by the mid-Permian, Carbonita at the end-Permian, while Darwinula survived but with a much reduced diversity (Horne, 2003). 
Only darwinulids and limnocytherids survived the endPermian extinction and are found in freshwaters today. This study supports the notion of brackish ostracods in the Mississippian (Tibert \& Scott, 1999; Williams et al. 2006). Previous studies have recorded freshwater Carbonita from the late Mississippian (Pendleian; Sohn, 1985), while this study records them from the mid-Mississippian (Arundian). The colonization of non-marine environments by ostracods is evident from the Carboniferous until the end-Permian, but it was only one of a series of such ostracod radiations, to be repeated many times. For example, the Cytheroidea are thought to have undertaken seven distinct nonmarine invasions from the Late Carboniferous to the present, the most active of which was during the Early Cretaceous (Horne, 2003; Tibert et al. 2003).

\section{Ostracod taxonomic notes}

Four new ostracod species are described in the Systematic Palaeontology Section 8 (authored by Bennett). Here, taxonomic notes are provided for the other species (Table 2, Figs 9-11), noting in some instances their first occurrence in the Mississippian sections studied. The familial and suprafamilial classification of ostracods from this study follows Whatley et al. (1993), supplemented by consideration of Sohn (1985) for the Superfamily Carbonitoidea, and Dewey \& Fåhraeus (1987) for the Family Geisinidae (Table 1).

\section{7.a. Order Podocopida Müller, 1894}

\section{7.a.1. Suborder Podocopina Sars, 1866}

Nine species from the families Bairdiidae (genera Acratia, Acutiangulata, Bairdia), Bairdiocyprididae (Silenites) and Carbonitidae (Carbonita) are recognized. Acratia sp. A. is identified by its lateral valve outline (Fig. 11q), which most closely resembles Acratia acuta (Jones \& Kirkby, 1895). Acutiangulata sp. A has a distinctly sub-quadrate lateral outline of the ventroposterior margin (Fig. 9a, d). Bairdia submucronata Jones \& Kirkby (1879a) (topotypes designated herein as NHM specimens In 42133, OS 7457 and OS 7458, the latter two figured by Jones \& Kirkby, 1879a and Robinson, 1978) possesses a postero-dorsal margin inclined at $10^{\circ}$ to the horizontal in lateral view (Fig. 9b). This species is similar to Bairdia altaica Buschmina \& Kononova, 1981 and $B$. beedei Ulrich \& Bassler, 1906, but with more central inflation to the carapace. Silenites sp. A is identified by its sub-ovate lateral carapace outline and external surface ornament of $20 \mu \mathrm{m}$ diameter reticulae (Fig. 11o). The posterior end of the carapace is higher and more inflated than the anterior, which may indicate sexual dimorphism.

Carbonita has a long history of taxonomic revision (see Pollard, 1966; Anderson, 1970; Sohn, 1977; Horne, 2003 and Tibert \& Dewey, 2006 for a summary). The Scottish specimens lack details of the muscle scar, and their assignment to Carbonita is tentative. Carbonita bairdioides (Jones \& Kirkby, $1879 b$ ) (lectotype designated here as NHM I 2566, fig. $\mathrm{d}$ in Athersuch et al. 2009) is distinguished by its subtriangular, asymmetrical, lateral carapace outline and arched dorsal margin (Fig. 11g). Carbonita cf. fabulina (Jones \& Kirkby, 1879b) has a more strongly arched dorsal margin and greater valve height versus length than C. bairdioides (Fig. 11a). Carbonita cf. humilis (Jones \& Kirkby, 1879b) is identified by its ovate, symmetrical, lateral carapace outline and external surface ornamentation of $20 \mu \mathrm{m}$ diameter reticulae (Fig. 11c). C. humilis is one of the most common non-marine ostracods in the Pennsylvanian of Britain (Pollard, 1966; Anderson, 1970; Athersuch et al. 2009) and exhibits sexual dimorphism (Bless \& Pollard, 1975). Carbonita cf. inflata (Jones \& Kirkby, 1879b) is sub-triangular to sub-rounded in lateral carapace outline (Fig. 11b), but lacks the punctate ornament of Pollard's (1966) material of C. inflata. Anderson (1970) regarded Bythocypris tumidus, Cypridopsis fabulina, Gutschickia ovata and Whipplella cuneiformis to be junior synonyms of $C$. inflata.

Our material extends the range of certain genera in the Mississippian of Britain: Acutiangulata from the Lower Asbian (Robinson, 1978) up to the Brigantian (this study); Bairdia submucronata from the Asbian (Robinson 1978; Turner, Dewey \& Fordham, 1997) to the Brigantian, and Carbonita from the Pennsylvanian (Athersuch et al. 2009) downwards to the Mississippian.

\section{7.a.2. Suborder Metacopina Sylvester-Bradley, 1961}

Healdia cf. cuneata Robinson, 1978 (from the family Healdiidae) is identified by its $85^{\circ}$ lateral angle of the posterior margin (Fig. 9g), and the presence of small posterior and postero-ventral spines (between 7-10 $\mu \mathrm{m}$ in length). While H. cuneata lacks spines (Robinson, 1978), other species have much larger spines, such as Healdia cornigera (Jones \& Kirkby, 1867).

\section{7.a.3. Suborder Platycopina Sars, 1866}

Four species from the families Cavellinidae ( $\mathrm{Cav}$ ellina), Geisinidae (Geisina) and Glyptolichvinella (family uncertain) are recognized. Owing to a lack of soft-part evidence, the relationship between Recent and Carboniferous platycopes is poorly understood (Horne, 2003). Cavellina benniei (Jones, Kirkby \& Brady, 1884) (topotypes designated here as NHM OS 7339, OS 7340 and specimens from slide I. 1725, the former two figured in Jones, Kirkby \& Brady, 1884 and Robinson, 1978) has a sub-quadrate lateral carapace outline (Fig. 10a). Cavellina valida (topotypes designated herein as NHM OS 7346 and OS 7347, fig. d in Jones, Kirkby \& Brady, 1884 and Robinson, 1978) is defined by the $85^{\circ}$ lateral angle of the posterior margin, lack of spines and right-over-left valve overreach 


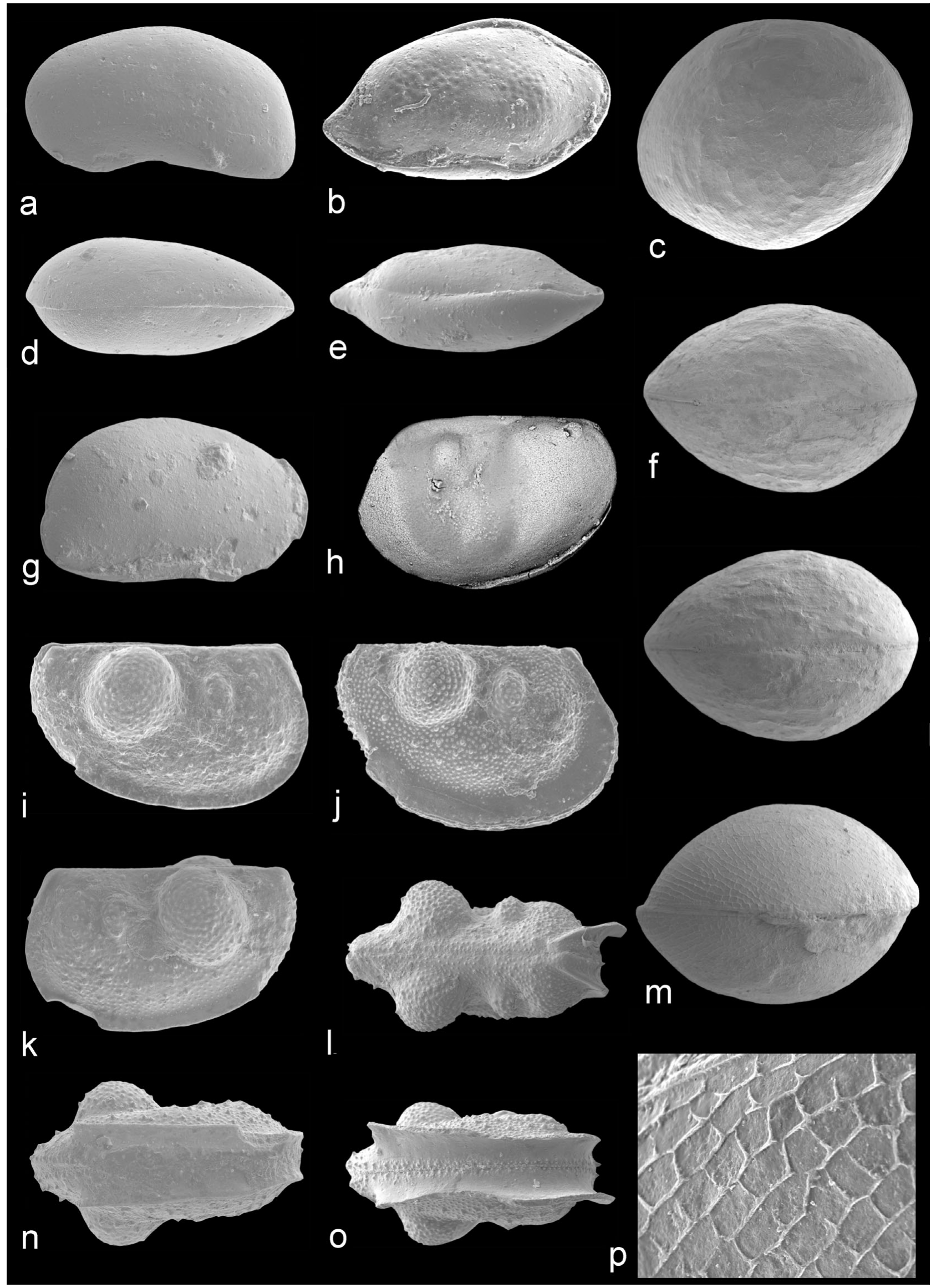

Figure 9. Marine ostracods. Specimen numbers are from the palaeontology collections of the BGS, Keyworth. All images are scanning electron micrographs. Acutiangulata sp. A: (a, d) carapace (MPK 13938; length $440 \mu \mathrm{m}$ ), left lateral and dorsal views, $\times 100$. Bairdia submucronata Jones \& Kirkby, 1879a: (b, e) carapace (MPK 13939; length $830 \mu \mathrm{m}$ ), right lateral and dorsal views, $\times 60$. Healdia cf. cuneata Robinson, 1978: (g) carapace (MPK 13941; length $420 \mu \mathrm{m}$ ), right lateral view, $\times 110$. Palaeocope sp. C: (h) carapace 
(Fig. 10e). Varying posterior inflation in adults indicates possible domiciliar sexual dimorphism, while the lack of inflation in C. benniei may reflect the small number of specimens identified (Table 2). Geisina arcuata Bean (1836) is identified by a shallow adductorial sulcus and a strong right-over-left valve overlap (Fig. 11i). A surface ornament of polygonal pitted reticulation (Pollard, 1966) is absent. Glyptolichvinella spiralis Jones \& Kirkby, 1880 (lectotype assigned here as NHM OS 7384, fig. d in Jones \& Kirkby, 1885 and Robinson, 1978) has an external ornamentation of costae in an open spiral pattern (Fig. 10g). The carapace size is larger than other species with similar costal patterns, such as Glyptolichvinella annularis (Kummerow, 1939).

\section{7.b. Order Leiocopida Schallreuter, 1973}

Four species from the family Paraparchitidae (Paraparchites armstrongianus (Jones \& Kirkby, 1886), Paraparchites circularis n. sp., Shemonaella ornata n. sp. and Shemonaella elongata $\mathrm{n}$. sp.) are recognized. The new species are described in the Systematic Palaeontology (Section 8). Paraparchites armstrongianus (Jones \& Kirkby, 1886) (lectotype assigned here as NHM I. 1756, fig. d in Jones \& Kirkby, 1886) has a distinct antero-cardinal spine (Fig. 10h), larger than that of other paraparchitids (such as species of Shishaella and Shivaella (Robinson, 1978; Sohn, 1972)).

\section{7.c. Order Palaeocopida Henningsmoen, 1953}

Five species from the family Hollinellidae (Hollinella (Keslingella)) and palaeocopes of uncertain affinity are identified. Hollinella (Keslingella) radiata (topotype assigned herein as NHM OS 7331, fig. d in Jones \& Kirkby, 1886 and Robinson, 1978) is distinguished by a small antero-dorsal node, a large postero-dorsal bulb, and an external ornament of tubercles and spines. The histium is twice as wide and the carapace is wider in some specimens (Fig. 9j), which are identified as heteromorphs (Kellett, 1936). Two adventral spines are present in juveniles, typical of the subgenus (Bless \& Jordan, 1970).

Palaeocopes spp. are classified into four species (A-D), but are left in open nomenclature owing to the small number of specimens identified (Table 2) and their differences to known palaeocope genera. All have a straight dorsal margin, preplete carapace and lobate ornamentation. A large posterior lobe or inflated posterior end in some specimens indicates sexual dimorphism. Species A-D are distinguished by differences in ornamentation. Palaeocope sp. A is quadrilobate (Fig. 10j), palaeocope sp. B trilobate, with spines on the anterior or anterior and posterior free margins (Fig. $10 \mathrm{~m}$, p). The spines are $20 \mu \mathrm{m}$ in length and vary in shape (triangular, clavellate (widens distally) or needle like) and position (closely or distally spaced) between specimens, indicative of intra-species variation. Jonesina fastigiata (Jones \& Kirkby, 1867) (fig. d in Robinson, 1978, pl. 4, figs 2ab) resembles palaeocope sp. B, but has more spherical lobes. Palaeocope sp. $\mathrm{C}$ is trilobate, distinguished by a postero-cardinal spine $(30 \mu \mathrm{m}$ in length) on the posterior lobe (Fig. 9h). Palaeocope sp. D is trilobate, with flattened valve free margins, reticulate external ornament and no spines (Fig. 11p).

\section{7.d. Order Myodocopida Sars, 1866}

Polycope elegans $\mathrm{n}$. sp. is the only representative of the family Polycopidae and is described in the following section.

\section{Systematic palaeontology (C. Bennett)}

Four new species are described from the Strathclyde Group. A differential diagnosis is given owing to the problems of otherwise distinguishing between species that have no or little carapace ornamentation.

Order LEIOCOPIDA Schallreuter, 1973

Suborder PARAPARCHITICOPINA Gramm \& Ivanov, 1975

Superfamily PARAPARCHITOIDEA Scott, 1959 Family PARAPARCHITIDAE Scott, 1959

Genus Paraparchites Ulrich \& Bassler, 1906

Type species. By original designation Paraparchites humerosus Ulrich \& Bassler, 1906.

Diagnosis. See Dewey \& Fåhraeus (1987), p. 108.

Paraparchites circularis $\mathrm{n}$. sp. Figure 11h, j-n

Holotype. MPK 13960, a left valve; length $800 \mu \mathrm{m}$; Fig. 11j.

Derivation of name. Latin circularis, 'circular', referring to the lateral valve shape.

Type locality. Sample SE 8411, at $363.2 \mathrm{~m}$ core depth, Kilconquhar borehole; the Sandy Craig Formation, Fife [National grid reference NO 4844 0304].

Material. See Table 2. The average (mean) size of adult carapaces is length $840 \mu \mathrm{m}$, height $740 \mu \mathrm{m}$, width $420 \mu \mathrm{m}$.

(juvenile; MPK 13989; length $350 \mu \mathrm{m}$ ), left lateral view, $\times$ 129. Polycope elegans $\mathrm{n} . \mathrm{sp}$ : (c, f) carapace (holotype; MPK 13942; length $1800 \mu \mathrm{m})$, right lateral and dorsal view (stereo pair), $\times 26 ;(\mathrm{m}, \mathrm{p})$ carapace $($ MPK 13943; length $1550 \mu \mathrm{m})$, subdorsal view $(\times 33)$, and rectangular reticulation (image $230 \mu \mathrm{m}$ wide; $\times 187$ ). Hollinella (Keslingella) radiata (Jones \& Kirkby, 1886): (i, k, n) carapace, tecnomorph (MPK 13973; length $875 \mu \mathrm{m})$, right lateral, left lateral and right ventral views, $\times 54$; $(\mathrm{j}, 1, \mathrm{o})$ carapace, heteromorph, (MPK 13977; length $1000 \mu \mathrm{m}$ ), right lateral, dorsal and ventral views, $\times 48$. 

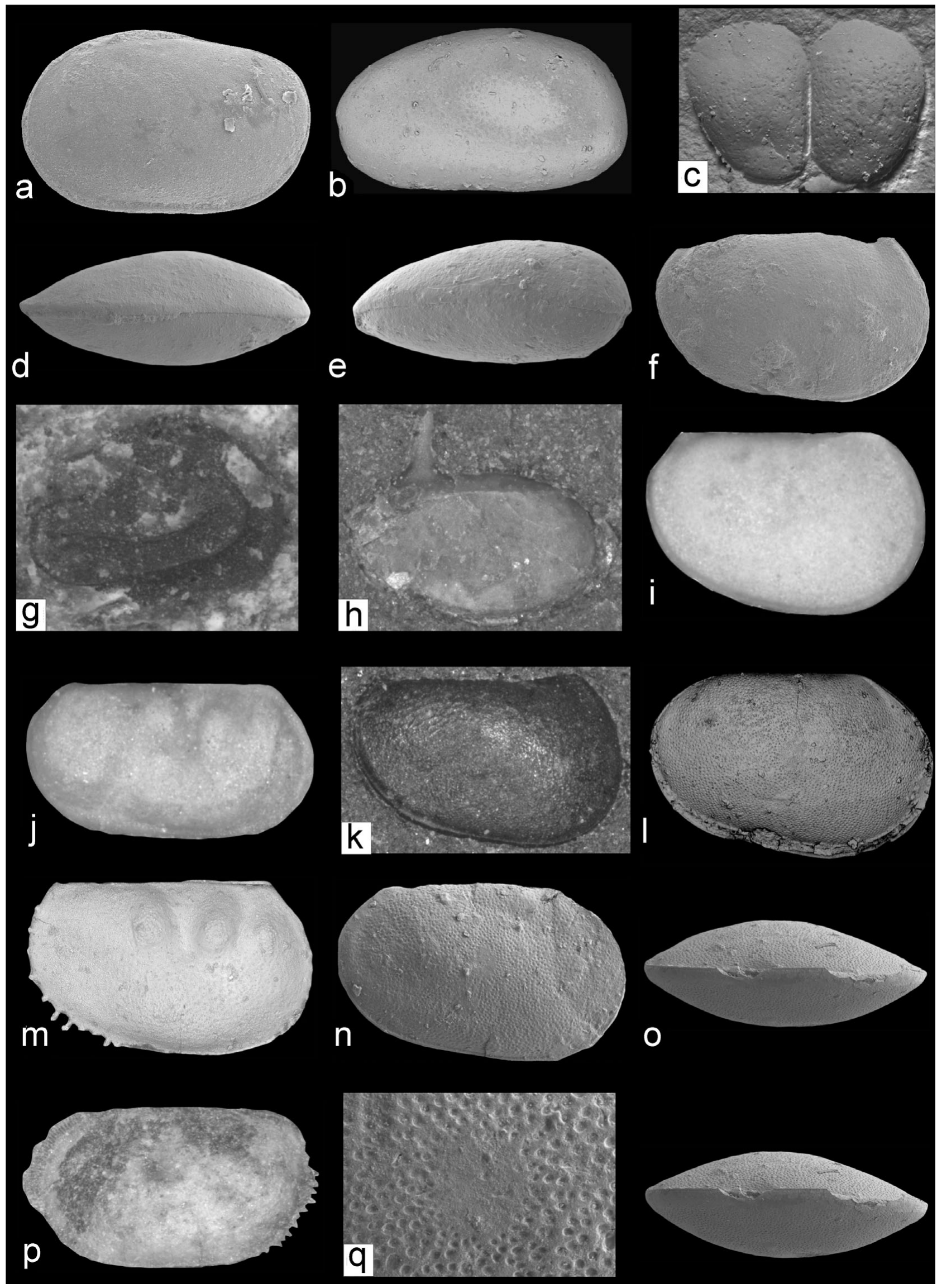

Figure 10. Eurytopic ostracods. Specimen numbers are from the palaeontology collections of the BGS, Keyworth. Images are scanning electron micrographs $(\mathrm{a}-\mathrm{f}, \mathrm{l}-\mathrm{o}, \mathrm{q})$ or light photographs $(\mathrm{g}-\mathrm{k}, \mathrm{p})$. Cavellina benniei (Jones, Kirkby \& Brady, 1884): (a, d) carapace (large juvenile; MPK 13944; length $540 \mu \mathrm{m}$ ) left lateral and dorsal views, $\times 91$. Cavellina valida (Jones, Kirkby \& Brady, 1884): (b, e) carapace (MPK 13945; length $570 \mu \mathrm{m}$ ), left lateral and dorsal views, $\times$ 84. Glyptolichvinella spiralis (Jones \& Kirkby, 1880) 
Differential diagnosis. Species of Paraparchites with a subcircular carapace outline in lateral view, except for a straight dorsal margin. The carapace has a high height:length ratio of $1: 1.1$. External surface of the valves have shallow circular punctae, each approximately $12 \mu \mathrm{m}$ in diameter, and a smooth sub-circular central muscle scar spot approximately $60 \mu \mathrm{m}$ in diameter. Paraparchites circularis $\mathrm{n}$. sp. has a valve height:length that is greater than other large Mississippian paraparchitoideans which also have a similar outline shape, such as Chamishaella suborbiculata (Münster, 1830), Paraparchites carbonaria (Hall), Paraparchites scotoburdigalensis (Hibbert, 1836) and Shemonaella scotoburdigalensis (Hibbert, 1836). Paraparchites discus Williams et al. 2005, has an incised dorsum and smaller height:length ratio than this species.

Description. Carapace sub-circular in lateral outline, amplete, symmetrical. Dorsal margin straight, two-thirds the total carapace length, ventral, anterior and posterior margins rounded. Height slightly less than length, valves are centrally inflated. Internal moulds have anastomosing structures radiating from a central muscle spot. Right-overleft valve overlap to give a ridge around the valve free margins.

Discussion. The anastomosing structures on the internal surface of valves may reflect part of the circulatory system, as has been proposed for leperditid arthropods (Vannier, Wang \& Coen, 2001). This species commonly occurs in monospecific assemblages or associated with rare Carbonita cf. inflata and Silenites sp. A. The genus is recorded from the Mississippian of Scotland (Latham, 1932; Williams et al. 2005), Canada (Dewey, 1988) and the USA (Benson, 1955; Sohn, 1971).

Genus Shemonaella Sohn, 1971

Type species. By original designation Shemonaella dutroi Sohn, 1971.

Diagnosis. See Dewey \& Fåhraeus (1987), p. 109.

Shemonaella elongata $\mathrm{n}$. sp. Figure 10c, f, i, k

Holotype. MPK 13964, a left valve; length $1200 \mu \mathrm{m}$; Fig. $10 \mathrm{i}$.

Derivation of name. The Latin elongata, 'long, or elongate', referring to the unusual length to height carapace proportions.
Type locality. Sample EN 4805, at $11.53 \mathrm{~m}$ core depth, Claremont borehole; the Pathhead Formation, Fife [National grid reference NO 4518 1419].

Material. See Table 2. Average dimensions: length $1200 \mu \mathrm{m}$, height $760 \mu \mathrm{m}$.

Differential diagnosis. Species of Shemonaella with a long dorsal margin ( $80 \%$ of the carapace length), shallow carapace inflation and an unusually high height:length ratio for this genus of 1:1.6. Many paraparchitoideans have the same carapace size, shape and lack of external ornamentation as this species. These include the postplete Shemonaella sp. A of Williams et al. 2005, Paraparchites inornatus McCoy, 1844, Paraparchites superbus (Jones \& Kirkby, 1886) and Shishaella sohnella Crasquin, 1985, and the preplete Leperditia okeni Münster (Jones \& Kirkby, 1865), Paraparchites nicklesi (Ulrich, 1891), Paraparchites okeni Münster, 1830 and Shishaella nanaformis Crasquin, 1985. However, these species are all more centrally inflated, with a shorter carapace height and a shorter dorsal margin to carapace length.

Description. Carapace semicircular in lateral outline, subamplete to postplete. Dorsal margin straight, $80 \%$ the total carapace length. Ventral margin curved, anterior and posterior margins rounded. Carapace large, inflated centrally and towards the posterior. Surface smooth, internal moulds have anastomosing structures radiating from a central muscle spot, which may preserve the circulatory system. Left-overright valve dorsal overreach.

Discussion. This is one of the most common species in the Strathclyde Group, often present in abundance, in all formations and in a range of ecological settings (Tables 2, 3, 5, Figs 7, 8). The genus is recorded from the Mississippian of Britain (Robinson, 1978), Germany (Coen, 1990) and Canada (Crasquin, 1985; Dewey, 1993; Dewey \& Fåhraeus, 1987).

\section{Shemonaella ornata $\mathrm{n} . \mathrm{sp}$.}

Figure 101, n, o, q

Holotype. MPK 13966, a carapace; length 1600 m; Fig. 101, o.

Derivation of name. The Latin ornata, 'ornate', referring to the distinctive pitted ornament.

Type locality. Sample EN 4804, at $11.53 \mathrm{~m}$ core depth, Claremont borehole; the Pathhead Formation, Fife [National grid reference NO 4518 1419].

\footnotetext{
- environment uncertain: (g) left valve (MPK 13949; length $1000 \mu \mathrm{m}$ ), lateral view, specimen partly obscured by dolomite crystals, $\times$ 46. Paraparchites armstrongianus (Jones \& Kirkby, 1886): (h) left valve of a disarticulated carapace (MPK 13950; length $1600 \mu \mathrm{m}$ ), lateral view, $\times 29$. Shemonaella elongata $\mathrm{n}$. sp.: (c) carapace (juvenile; MPK 13968; height of valve $385 \mu \mathrm{m}$ ), silicon rubber cast, $\times$ 73; (f) left valve (MPK 13965; length $1220 \mu \mathrm{m}$ ), lateral view, specimen broken at dorsal margin, $\times 41$; (i) left valve (MPK 13964; holotype; CEB7; length $1200 \mu \mathrm{m}$ ), lateral view, $\times$ 39; (k) right valve (MPK 13967; length $1000 \mu \mathrm{m}$ ), internal mould, with anastomosing structures, $\times$ 48. Shemonaella ornata $\mathrm{n}$. sp.: (1, o) carapace (MPK 13966; holotype; CEB6; length $1600 \mu \mathrm{m})$, left lateral and ventral (stereo pair) views, $\times 30$; (n, q) left valve (MPK 13969; length $1400 \mu \mathrm{m})$, lateral view $(\times 34)$, and external view of the adductor muscle scar $(120 \mu \mathrm{m}$ diameter, $\times 131)$. Palaeocope sp. A: (j) right valve (MPK 13980; length $850 \mu \mathrm{m})$, lateral view, $\times 58$. Palaeocope sp. B: (m) carapace (MPK 13984; length $630 \mu \mathrm{m}$ ), right lateral view, $\times 75$; (p) left valve (MPK 13986; length $700 \mu \mathrm{m})$, lateral view, flattened specimen, $\times 70$.
} 

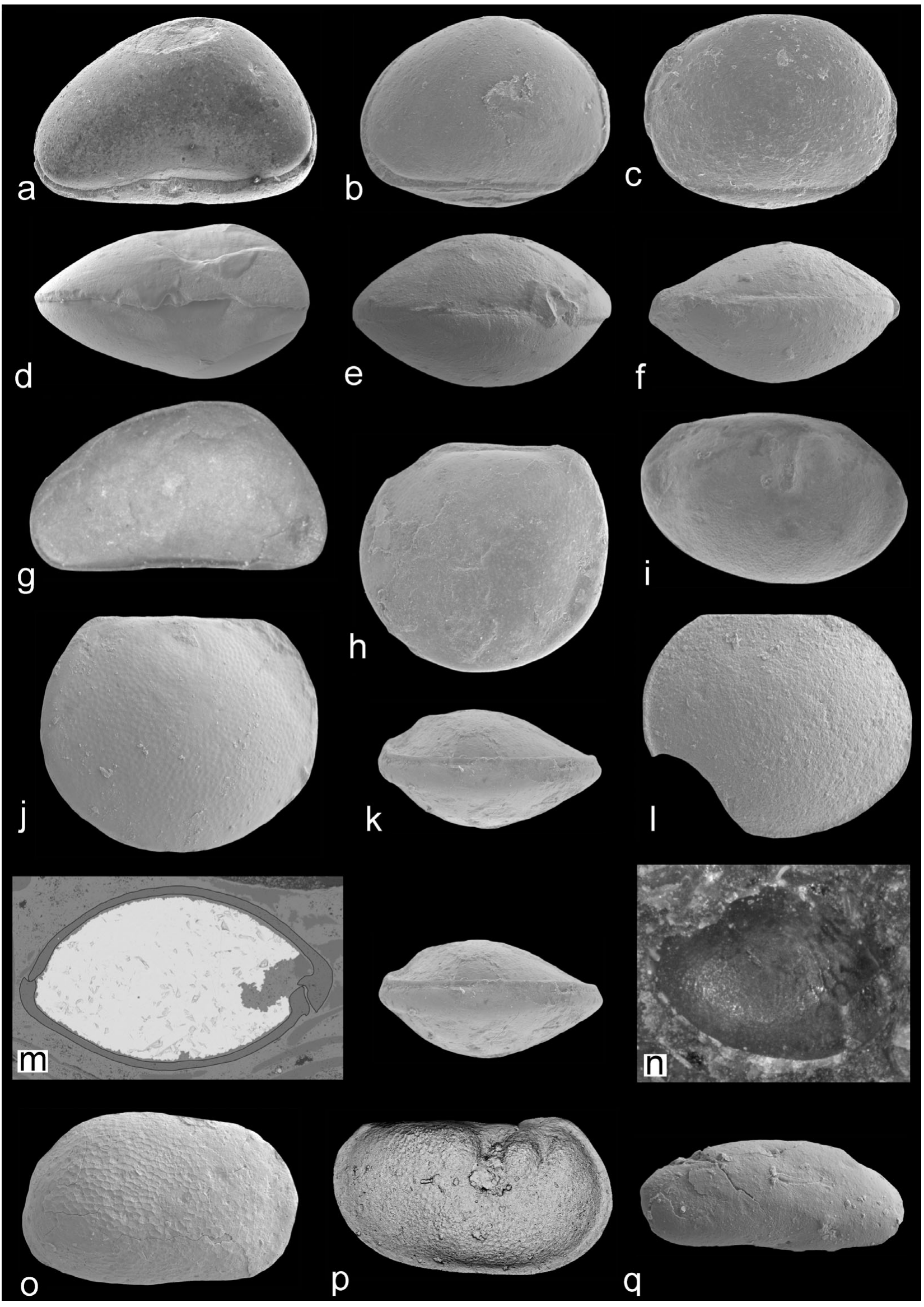

Figure 11. Freshwater $(\mathrm{a}-\mathrm{g})$, freshwater-brackish $(\mathrm{h}-\mathrm{o})$ and 'ecology uncertain' $(\mathrm{p}, \mathrm{q})$ ostracods. Specimen numbers are from the palaeontology collections of the BGS, Keyworth. Images are scanning electron micrographs $(\mathrm{a}-\mathrm{f}, \mathrm{h}-\mathrm{m}, \mathrm{o}-\mathrm{q})$ or light photographs $(\mathrm{g}$, n). Carbonita cf. fabulina (Jones \& Kirkby, 1879b): (a, d) carapace (MPK 13955; length $940 \mu \mathrm{m}$ ), left lateral and ventral views, $\times 51$. Carbonita cf. inflata (Jones \& Kirkby, 1879b): (b, e) carapace (MPK 13953; length $875 \mu \mathrm{m}$ ), left lateral and dorsal views, $\times 48$. 
Material. See Table 2. Average dimensions: length $1450 \mu \mathrm{m}$, height $920 \mu \mathrm{m}$, width $500 \mu \mathrm{m}$.

Differential diagnosis. Species of Shemonaella with an ornament of $10 \mu \mathrm{m}$ diameter circular pits and a circular, smooth muscle scar spot (120 $\mu \mathrm{m}$ diameter) situated at the midpoint. This species has a larger carapace size and a unique ornament for Shemonaella, compared to other species of the genus. The dorsal margin is comparatively shorter than that of Shemonaella elongata $\mathrm{n}$. sp. Specimens of Leperditia youngiana Jones \& Kirkby, 1867 from the NHM 'Jones collection' has a similar carapace size, but an ornament of $5 \mu \mathrm{m}$ diameter pits, not the $10 \mu \mathrm{m}$ diameter pits of this new species.

Description. Carapace sub-ovate in lateral outline, postplete. Dorsal margin straight, two-thirds the total carapace length. Ventral margin straight, sloping towards the anterior; anterior and posterior ends rounded. The posterior end is distinctly higher than the anterior end. Carapace large for the genus, centrally inflated. Right-over-left valve overlap around all free margins excluding the dorsal margin.

Discussion. This species is limited in number of specimens and restricted in distribution compared to Shemonaella elongata n. sp. (Table 2, 3, Figs 7, 8).

Order MYODOCOPIDA Sars, 1866

Suborder CLADOCOPINA Sars, 1866

Superfamily POLYCOPOIDEA Sars, 1866

Family POLYCOPIDAE Sars, 1866

Genus Polycope Sars, 1866

Type species. By original designation Polycope orbicularis Sars, 1866.

Diagnosis. See Sars (1928), pp. 29-30.

Polycope elegans $\mathrm{n}$. sp. Figure 9c, f, m, p

Holotype. MPK 13942, a carapace; length $1800 \mu \mathrm{m}$; Fig. 9c, f.

Derivation of name. The Latin elegans, 'beautiful/elegant', referring to the beautiful, fine reticulate ornamentation.

Type locality. Sample EN 5329, at $74.93 \mathrm{~m}$ core depth, Denork borehole; the Pathhead Formation, Fife [National grid reference NO 4540 1409].

Material. See Table 2. Dimensions: length $1800 \mu \mathrm{m}$, height $1580 \mu \mathrm{m}$, width $1250 \mu \mathrm{m}$ : MPK 13942.
Differential diagnosis. Polycope with a large carapace size and a unique radial pattern of hexagonal (at the valve centre) to rectangular (at the valve edge) reticulation. The reticulae are $40 \mu \mathrm{m}$ in diameter. Other Mississippian Polycope mostly have a smaller carapace size, for example Polycope sphaerula (Gründel, 1961) and Polycope spinula Dewey \& Fåhraeus, 1987. Polycope youngiana Jones, Kirkby \& Brady, 1874 resembles the new species in size and shape, but it has an ornament of concentrically ringed grooves rather than reticulae, that is distinctly different.

Description. Carapace sub-circular in lateral outline, subspherical in shape, postplete. Dorsal margin straight, onethird the total carapace length, all other margins rounded. Carapace large, thick shelled, tumid. External surface ornament of reticulae arranged in a radial pattern from the midpoint. Reticulae change shape from hexagonal or polygonal in the valve centre, to rectangular or square at the edges of the valve. No valve overlap.

Discussion. This species is only found in the Denork core of the Pathead Formation. The four samples that contain Polycope elegans n. sp. are each spaced at least a metre apart, suggesting that this species was present for a significant time interval. Other species of Polycope have been described from the Devonian/Carboniferous of Germany (Becker, ClausDieter \& Klaus, 1993), the Mississippian of Northumberland (Dewey, 1993) and the Maritimes Basin of Canada (Dewey, 1988; Dewey \& Fåhraeus, 1987).

\section{Conclusions}

(1) The Strathclyde Group of Fife, Scotland, represents a range of different depositional settings and environments, from fully marine conditions to deltaic sediments, marginal marine estuaries and lagoons, and brackish to freshwater lakes, swamps and fluvial systems. Ostracods and other fossils inhabited marine, brackish and freshwater environments. These deposits contain 25 ostracod species, including 4 that are new species.

(2) Macrofossil indicators of freshwater are the bivalves Anthraconaia, Carbonicola and Cardiopteridium, Spinicaudata, fish and plant debris.

(3) The Mississippian of the MVS contains some of the earliest freshwater ostracods globally. Freshwater Carbonita is described from the Arundian, middle Mississippian, in organic-rich mudstones and stromatolitic limestones. This study places the first freshwater ostracods approximately $15 \mathrm{Ma}$ earlier than previously documented at $325 \mathrm{Ma}$.

(4) Brackish to freshwater macrofauna includes Naiadites, Curvirimula and 'Spirorbis'. Brackish water

Carbonita cf. humilis (Jones \& Kirkby, 1879b): (c, f) carapace (MPK 13956; length $840 \mu \mathrm{m}$ ), left lateral and ventral views, $\times 50$ Carbonita bairdioides (Jones \& Kirkby, 1879b): (g) carapace (MPK 13957; length $800 \mu \mathrm{m}$ ), left lateral view, $\times 63$. Geisina arcuata (Bean, 1836): (i) carapace (MPK 13959; length $610 \mu \mathrm{m}$ ), right lateral view, $\times 74$. Paraparchites circularis $\mathrm{n} . \mathrm{sp} .:(\mathrm{h}, \mathrm{k}) \mathrm{carapace}$ (juvenile; MPK 13958; length $850 \mu \mathrm{m}$ ), left lateral and ventral (stereo pair) views, $\times$ 49; (j) left valve (holotype; MPK 13960; length $800 \mu \mathrm{m}$ ), lateral view, $\times 58$; (1) right valve (MPK 13961; length $720 \mu \mathrm{m}$ ), lateral view, $\times 64$; (m) carapace (juvenile; MPK 13962; thin-section; length $600 \mu \mathrm{m}$ ), the valves are outlined in black, the hinge is to the left, $\times 87$; (n) carapace (MPK 13963 ; image $800 \mu \mathrm{m}$ wide), oblique view of an internal skeinkern, central muscle spot and anastomosing structures, $\times 54$. Silenites sp. A: (o) right valve (MPK 13971; length $680 \mu \mathrm{m}$ ), lateral view, $\times 68$. Palaeocope sp. D: (p) carapace (MPK 13991; length $700 \mu \mathrm{m}$ ), right lateral view, $\times 71$. Acratia sp. A: (q) single valve (MPK 13951; length $324 \mu \mathrm{m}$ ), lateral view, $\times 133$. 
ostracods are Geisina arcuata, Paraparchites circularis n. sp., Shemonaella ornata n. sp. and Silenites sp. A.

(5) Typical macrofossil indicators of marginal marine conditions are Schizodus, Sanguinolites and Lingula. Ostracods that are eurytopic, with a wide salinity tolerance, are Cavellina benniei, Cavellina valida, palaeocope species A and B, Paraparchites armstrongianus and Shemonaella elongata $\mathrm{n}$. sp.

(6) Marine ostracods are Acutiangulata sp. A, Bairdia submucronata, Healdia cf. cuneata, Hollinella (Keslingella) radiata, palaeocope sp. $\mathrm{C}$ and Polycope elegans $\mathrm{n}$. sp. They occur with a high diversity of marine macrofauna such as brachiopods, bryozoans, echinoderms and gastropods.

(7) The drivers of non-marine colonization by ostracods in the Mississippian can only be speculated upon, but may involve environmental (sea-level) change due to glaciation. The mechanisms to adapt to lower salinity such as osmoregulation and changes in reproduction are not fully known owing to a lack of knowledge of relevant soft parts. For example, there is insufficient evidence to suggest that desiccationresistant eggs had developed during the Carboniferous, but links can be made to contemporaneous arthropods and living freshwater ostracods.

(8) Despite the success of the non-marine platycopes, podocopes and leiocopes, the majority did not survive the end-Permian extinction. Instead ostracods underwent a further series of terrestrial aquatic colonization events in the Mesozoic.

Acknowledgements. The Natural Environment Research Council (NERC) funded the project, grant number NER/S/A/2005/13368. The British Geological Survey (BGS) provided additional CASE award funding through the British Universities Funding Initiative. The following are thanked from the BGS for their advice and providing access to samples: Drs Maxine Akhurst, Sarah Arkley and Mike Howe, and Mr Mark Dean. All figured specimens are housed in the BGS palaeontology collections, Keyworth. The following are thanked for correspondence and/or discussions about Carboniferous ostracods and fossils: Prof. Alan Lord, and Drs Dave Horne, Chris Dewey, Neil Tibert, John Pollard, Adrian Rundle, Luis Carlos Sánchez de Posada and Zerina Johanson. Two authors (IPW and MB) publish with permission of the Executive Director of the BGS (NERC).

\section{References}

Aladin, N. V. \& PotTs, W. T. W. 1996. The osmoregulatory capacity of the Ostracoda. Journal of Comparative Physiology B 166, 215-22.

Algeo, T. J., BERnER, R. A., MAYNARD, J. B. \& SCHECKLER, S. E. 1995. Late Devonian ocean anoxic events and biotic crises: "rooted" in the evolution of vascular land plants? GSA Today 5, 46-66.

ANDERSON, F. W. 1970. Carboniferous ostracoda of the genus Carbonita Strand. Bulletin of the Geological Survey of Great Britain 32, 69-121.

Anderson, L. I., Dunlop, J. A., EAGar, R. M. C., HorRoCKS, C. A. \& Wilson, H. M. 1999. Soft-bodied fossils from the roof shales of the Wigan Four Foot coal seam, Westoughton, Lancashire, UK. Geological Magazine 135, 321-29.
Athersuch, J., Gooday, A. J., Pollard, J. E. \& Riley, N. J. 2009. Carboniferous. In Ostracods in British Stratigraphy (eds J. E. Whittaker \& M. B. Hart), pp. 11153. London: The Micropalaeontological Society Special Publications.

BALlĖVRE, M. \& LARDEUX, H. 2005. Signification paléoécologique et paléogéographique des bivalves du Carbonifère inférieur du bassin d'Ancenis (Massif armoricain). Paléontologie Systématique 4, 109-21.

Bateman, R. M., Crane, P. R., DiMichele, W. A., Kenrick, P. R., Rowe, N. P. \& SPECK, T. 1998. Early evolution of land plants: phylogeny, physiology, and ecology of the primary terrestrial radiation. Annual Review of Ecological Systems 29, 263-92.

BEAN, W. 1836. Description and figures of Unio distortus Bean, and Cypris concentrica Bean, from the Upper Sandstone and shale of Scarborough, and Cypris arcuata Bean, from the coal formation of Newcastle. Magazine of Natural History 9, 376-7.

Becker, G., Claus-Dieter, C. \& Klaus, L. 1993. Verkieselte Ostracoden vom Thüringer Ökotyp aus dem Grenzbereich Devon/Karbon des Steinbruchs Drewer (Rheinisches Schiefergebirge). Courier Forschungsinstitut Senckenberg 17, 1-130.

BennetT, C. E. 2008. A review of the Carboniferous colonisation of non-marine environments by ostracods. Senckenbergiana Lethaea 88, 37-46.

BENNISON, G. M. 1960. Lower Carboniferous non-marine lamellibranchs from East Fife, Scotland. Palaeontology 3, 137-52.

BENNISON, G. M. 1961. Small Naiadites obesus from the Calciferous Sandstone Series (Lower Carboniferous) of Fife. Palaeontology 4, 300-11.

BENSON, R. H. 1955. Ostracodes from the type section of the Fern Glen Formation. Journal of Paleontology 29, 1030-9.

Bless, M. J. M. 1983. Late Devonian and Carboniferous ostracode assemblages and their relationship to the depositional environment. Bulletin de la Société Belge de Géologie 92, 31-53.

Bless, M. J. M. \& Jordan, H. 1970. Stratigraphical and taxonomical remarks on the ostracode genus Hollinella Coryell. Mededelingen Rijks Geologische Dienst 21, 81-91.

Bless, M. J. M. \& JORDAN, H. 1971. The new genus Copelandella from the Carboniferous - the youngest known beyrichioidean ostracodes. Lethaia 4, 185-90.

Bless, M. J. M. \& POLlaRD, J. E. 1973. Paleoecology and Ostracode Faunas of Westphalian Ostracode Bands from Limburg, The Netherlands and Lancashire, Great Britain. Mededelingen Rijks Geologische Dienst, Nieuwe Serie 24, 21-53.

Bless, M. J. M. \& Pollard, J. E. 1975. Quantitative analysis of dimorphism in Carbonita humilis (Jones and Kirkby). American Bulletin of Paleontology 65, 109-27.

Bless, M. J. M., Streel, M. \& BeCKer, G. 1988. Distribution and palaeoenvironment of Devonian to Permian ostracod assemblages in Belgium with reference to some Late Famennian to Permian marine nearshore to "brackish-water" assemblages dated by miospores. Annales de la Société Géologique de Belgique 110, 34762.

BOARDMAN, E. L. 1989. Coal measures (Namurian and Westphalian) Blackband Iron Formations: fossil bog iron ores. Sedimentology 36, 621-33.

Boomer, I., Horne, D. J. \& SLIPPER, I. J. 2003. The use of ostracods in palaeoenvironmental studies, or what can you do with an ostracod shell? In Bridging the Gap: Trends in the ostracode biological and geological 
sciences (eds L. E. Park \& A. J. Smith), pp. 153-79. The Paleontological Society Papers, vol. 9.

BRAND, U. 1994. Continental hydrology and climatology of the Carboniferous Joggins Formation (lower Cumberland Group) at Joggins, Nova Scotia: evidence from the geochemistry of bivalves. Palaeogeography, Palaeoclimatology, Palaeoecology 106, 307-21.

BRAND, P. J. 1996. Taxonomy and distribution of the Upper Carboniferous non-marine bivalve Carbonicola aldamii. Palaeontology 39, 407-11.

Browne, M. A. E., DeAn, M. T., Hall, I. H. S., McAdam, A. D., Monro, S. K. \& Chisholm, J. I. 1999. A lithostratigraphical framework for the Carboniferous rocks of the Midland Valley of Scotland. BGS research report $\mathrm{RR} / 99 / 07$.

Buatois, L. A., Gingras, M. K., MACEAChERN, J., MÁngano, M. G., Zonneveld, J. P., Pemberton, S. G., Netto, R. G. \& MARTin, A. 2005. Colonization of brackish-water systems through time: evidence from the trace-fossil record. Palaios 20, 321-47.

Buatois, L. A., Mángano, M. G., Genise, J. F. \& TAYlor, T. N. 1998. The ichnological record of the invertebrate invasion of non-marine ecosystems: evolutionary trends in ecospace utilisation, environmental expansion, and behavioral complexity. Palaios 13, 217-40.

Burchette, T. P. \& RiDing, R. 1977. Attached vermiform gastropods in Carboniferous marginal marine stromatolites and biostromes. Lethaia 10, 17-28.

BuschminA, L. S. 1968. Early Carboniferous Ostracoda of the Kuznetsk Basin. Moscow: Izdatelstvo nauka, $128 \mathrm{pp}$.

BusCHMINA, L. S. \& KONONOVA, L. I. 1981. Microfauna and biostratigraphy of the Devonian-Carboniferous Beds of the south of the western Siberia. Academy of Sciences of the USSR, Siberian Branch, Institute of Geology and Geophysics, Transaction 459, 1-121.

Carbonel, P., Colin, J.-P., DANiElopol, D., LÖFFler, H. \& Neustrueva, I. 1988. Paleoecology of limnic ostracodes: a review of some major topics. Palaeogeography, Palaeoclimatology, Palaeoecology 62, 413-6.

Clarkson, E. N. K., Harper, D. A. T. \& Hoey, A. N. 1998. Basal Wenlock biofacies from the Girvan district, SW Scotland. Scottish Journal of Geology 34, 61-71.

COEN, M. 1990. Revision of Münster's Carboniferous ostracode species. Courier Forschungsinstitut Senckenberg 123, 265-73.

Coen, M., Michiels, D. \& PARISSE, E. 1988. Ostracodes dinantiens de l'Ardenne. Mémoires de l'Institut Géologique de l'Université de Louvain 34, 1-42.

CORYEll, H. N. 1928. Some new Pennsylvanian ostracodes. Journal of Paleontology 2, 87-94.

Coryell, H. N. \& BoOTh, R. T. 1933. Pennsylvanian Ostracoda: a continuation of the study of the Ostracoda from the Wayland Shale, Graham, Texas. The American Midland Naturalist 14, 258-79.

CrASQUIN, S. 1985. Zonation par les ostracodes dans le Mississippian de l'ouest Canadien. Revue de Paléobiologie 4, 43-52.

DAESCHLER, E. B. 2000. An early actinopterygian fish from the Catskill Formation (Late Devonian, Famennian) in Pennsylvania, U.S.A. Proceedings of the Academy of Natural Sciences of Philadelphia 150, 181-92.

DAVAUD, E. \& GIRARDCLOS, S. 2001. Recent freshwater ooids and oncoids from western Lake Geneva (Switzerland): indications of a common organically mediated origin. Journal of Sedimentary Research 71, 423-9.

Delo, D. M. 1930. Some Upper Carboniferous Ostracoda from the shale basin of western Texas. Journal of Paleontology 4, 152-78.
DEWEY, C. P. 1983. Ostracode palaeoecology of the Lower Carboniferous of Western Newfoundland. In Applications of Ostracoda (ed. R. F. Maddocks), pp. 104-15. University of Houston Geosciences.

DEWEY, C. P. 1987. Palaeoecology of a hypersaline Carboniferous ostracod fauna. Journal of Micropalaeontology 6, 29-33.

DEWEY, C. P. 1988. Lower Carboniferous ostracodes from the Maritimes Basin of eastern Canada: a review. Atlantic Geology 25, 63-71.

DEWEY, C. 1993. Palaeoecology of ostracodes from a Lower Carboniferous chemosynthetic community. In Ostracoda in the Earth and Life Sciences (eds K. G. McKenzie \& P. J. Jones), pp. 77-89. Proceedings of the 11th International Symposium on Ostracoda, Warrnambool, Victoria, Australia, 1991.

DeweY, C. P. \& FÅhraEUS, L. E. 1987. Taxonomy of Ostracoda (Crustacea) from Mississippian strata of maritime Canada. Geologica et Palaeontologica 21, 93 135.

Dineley, D. L. \& MetCALF, S. J. 1999. British Carboniferous fossil fishes sites. In Fossil Fishes of Great Britain (ed. D. Palmer), pp. 265-312. Peterborough, UK: The Geological Conservation Review Series, Joint Nature Conservation Committee.

EAgar, R. M. C. \& Belt, E. S. 2003. Succession, palaeoecology, evolution, and speciation of Pennsylvanian non-marine bivalves, Northern Appalacian Basin, USA. Geological Journal 38, 109-43.

EGOROV, V. G. 1950. Ostracodes from the Frasnian of the Russian Platform, I, Kloedenillidae. MoscowLeningrad: VNIGRI.

FALCON-LANG, H. J. 2005. Small cordaitalean trees in a marine-influenced coastal habitat in the Pennsylvanian Joggins Formation, Nova Scotia. Journal of the Geological Society, London 162, 485-500.

Falcon-LanG, H. J., Benton, M. J., Braddy, S. J. \& DAVIES, S. J. 2006. The Pennsylvanian tropical biome reconstructed from the Joggins Formation of Nova Scotia, Canada. Journal of the Geological Society, London 163, 1-16.

FERGUSON, L. 1962. The paleoecology of a Lower Carboniferous marine transgression. Journal of Paleontology 36, 1090-107.

FERGUSON, L. 1963. The paleoecology of Lingula squamiformis Phillips during a Scottish Mississippian marine transgression. Journal of Paleontology 37, 669-81.

FIELDING, C. R., FRANK, T. D. \& IsBell, J. L. 2008. The late Paleozoic ice age - a review of current understanding and synthesis of global climate patterns. Geological Society of America Special Paper 441, 343-54.

FLOYD, J. D. \& Williams, M. 2003. A revised correlation of Silurian rocks in the Girvan district, SW Scotland. Transactions of the Royal Society of Edinburgh: Earth Sciences 93, 383-92.

Freytet, P., BROUTIN, J. \& DURAND, M. 2000. Distribution and palaeoecology of freshwater algae and stromatolites: III, some new forms from the Carboniferous, Permian and Triassic of France and Spain. Annals de Paléontology 86, 195-241.

FREYTET, P. \& VERRECCHIA, E. P. 1998. Freshwater organisms that build stromatolites: a synopsis of biocrystallization by prokaryotic and eukaryotic algae. Sedimentology 45, 535-63.

FRIEDMAN, G. M. \& LUNDIN, R. F. 1998. Freshwater ostracodes from Upper Middle Devonian fluvial facies, Catskill Mountains, New York. Journal of Paleontology 72, 485-90. 
Friend, P. F. \& MoOdY-STUART, M. 1970. Carbonate deposition on the river floodplains of the Wood Bay Formation (Devonian) of Spitzbergen. Geological Magazine 107, 181-95.

GRAMM, M. N. \& IVANOV, V. K. 1975. The ostracod Paraparchites minax ivanov sp. nov. from the Permian of the U.S.S.R. and its muscle-scar field. Palaeontology 18, 551-61.

GRAY, J. 1988. Evolution of the freshwater ecosystem: the fossil record. Palaeogeography, Palaeoclimatology, Palaeoecology 62, 1-214.

GRÜNDEL, J. 1961. Zur biostratigraphie und fazies der Gattendorfia-Stufein Mitteldeutschland und besonderer berücksichtigung der Ostracoden. Freiberger Forschungshefte C 111, 53-173.

GuirdHAM, C., ANDREWS, J. E., BROWNE, M. A. E. \& DEAN, M. T. 2003. Stratigraphic and palaeoenvironmental significance of microbial carbonates in the Asbian Sandy Craig Formation of Fife. Scottish Journal of Geology 39, 151-68.

HARLTON, B. H. 1933. Micropaleontology of the Pennsylvanian Johns Valley Shale of the Ouachita Mountains, Oklahoma, and its relationship to the Mississippian Caney Shale. Journal of Paleontology 7 , 3-29.

Hartley, A. J. 1993. A depositional model for the MidWestphalian A to late Westphalian B Coal Measures of South Wales. Journal of the Geological Society, London 150, 1121-36.

HeBerT, B. L. \& CALDER, J. H. 2004. On the discovery of a unique terrestrial faunal assemblage in the classic Pennsylvanian section at Joggins, Nova Scotia. Canadian Journal of Earth Sciences 41, 247-54.

Heckel, P. H. \& Clayton, G. 2006. The Carboniferous System. Use of the new official names for the subsystems, series, and stages. Geological Acta 4, 4037.

HenNINGSMOEN, G. 1953. Classification of Paleozoic straight-hinged ostracods. Norsk Geologisk Tidsskrift 31, 185-288.

HiBBERT, S. 1836. On the freshwater limestones of Burdiehouse in the neighbourhood of Edinburgh, belonging to the Carboniferous Group of rocks. With supplementary notes on freshwater limestones. Transactions of the Royal Society of Edinburgh 13, 169-241.

HMich, D., SChNeIDER, J. W., SABER, H., VOIGHT, S. \& EL WARTITI, M. 2006. New continental Carboniferous and Permian faunas of Morocco: implications for biostratigraphy, palaeobiogeography and palaeoclimate. In Nonmarine Permian Biostratigraphy and Biochronology (eds S. G. Lucas, G. Cassinis \& J. W. Schneider), pp. 297-324. Geological Society of London, Special Publication no. 265.

HORNE, D. J. 2003. Key events in the ecological radiation of the Ostracoda. In Bridging the Gap: Trends in the ostracode biological and geological sciences (eds L. E. Park \& A. J. Smith), pp. 181-201. The Paleontological Society Papers, vol. 9.

JENKINS, T. B. H. 1960. Non-marine lamellibranch assemblages from the Coal Measures (Upper Carboniferous) of Pembrokeshire West Wales. Palaeontology 3, 104-23.

JoHnson, W. R. 1936. The ostracods of the Missouri series in Nebraska. Nebraska Geological Survey Paper 11, $1-52$.

JONES, P. J. \& CHEN, P. J. 2000. Carboniferous and Permian Leaioidea (Branchiopoda: Conchostraca) from Australia: taxonomic revision and biostratigraphic im- plications. Records of the Australian Museum 52, 223 44.

Jones, T. R. \& KirkBy, J. W. 1865. Notes on Palaeozoic bivalved Entomostraca, No. V. Münster's species from the Carboniferous Limestone. The Annals and Magazine of Natural History, London series 3, 15, 404-10.

JONES, T. R. \& KIRKBY, J. W. 1867. On the Entomostraca of the Carboniferous rocks of Scotland. Transactions of the Geological Society of Glasgow 2, 213-28.

JoneS, T. R. \& KIRKBY, J. W. 1879a. Description of the species of the ostracodous genus Bairdia McCoy, from the Carboniferous strata of Great Britain. Quarterly Journal of the Geological Society, London 35, 565-81.

Jones, T. R. \& KIRKBY, J. W. $1879 b$. Notes on Palaeozoic bivalved Entomostraca, No. XII. Some Carboniferous species belonging to the genus Carbonia, Jones. The Annals and Magazine of Natural History, London series $5,4,28-40$.

JONES, T. R. \& KIRKBY, J. W. 1880. On the zones of marine fossils in the Calciferous Sandstone Series of Fife. Quarterly Journal of the Geological Society, London 36, 559-90.

Jones, T. R. \& KIRKBY, J. W. 1885. Notes on Palaeozoic bivalved Entomostraca, No. XIX. On some Carboniferous Species of the Ostracodous genus Kirkbya, Jones. The Annals and Magazine of Natural History, London series $5,15,174-90$.

Jones, T. R. \& KirkBy, J. W. 1886. Notes on Palaeozoic bivalved Entomostraca, No. XXII. On some undescribed species of British Carboniferous Ostracoda. The Annals and Magazine of Natural History, London series 5, 18, 249-69.

JoNES, T. R. \& KIRKBY, J. W. 1895. Notes on Palaeozoic bivalved Entomostraca, No. XXXII. Some Carboniferous Ostracoda from Yorkshire. The Annals and Magazine of Natural History, London series 6, 16, 452-60.

Jones, T. R., KirkBy, J. W. \& Brady, G. S. 1874. A monograph of the British fossil bivalved Entomostraca from the Carboniferous Formations. Part 1, number 1 . The Cypridinidae and their allies. Monograph of the Palaeontographical Society, London 1-56.

Jones, T. R., KirkBy, J. W. \& Brady, G. S. 1884. A monograph of the British fossil bivalved Entomostraca from the Carboniferous Formations. Part 1, number 2. The Cypridinidae and their allies. Monograph of the Palaeontographical Society, London 57-99.

Kassi, A. M., Weir, J. A., McManus, J. \& Browne, M. A. E. 2004. Lithofacies and sedimentary cycles within the Late Dinantian (late Brigantian) of Fife and East Lothian: is a sequence stratigraphical approach valid? Transactions of the Royal Society of Edinburgh: Earth Sciences 94, 95-113.

Kellett, B. 1936. Carboniferous ostracods. Journal of Paleontology 10, 769-84.

KNOX, L. W. \& GORDON, E. A. 1999. Ostracodes as indicators of brackish water environments in the Catskill Magnafacies (Devonian) of New York State. Palaeogeography, Palaeoclimatology, Palaeoecology 148, 9-22.

KEYSER, D. 2005. Histological peculiarities of the noding process in Cyprideis torosa (Jones) (Crustacea, Ostracoda). Hydrobiologia 538, 95-106.

KumMEROw, E. H. E. 1939. Die Ostrakoden und phyllopoden des deutschen unterkarbons. Abhandlungen der Preussischen Geologischen Landesanstalt, Berlin. Neue Folge, Heft 194, 4, 1-107.

KUMMEROW, E. 1953. Über oberkarbonische und devonische Ostracoden in Deutschland und in der Volksrepublik Polen. Beiheft zur Zeitschrift Geologie 7, 3-75. 
Latham, M. H. 1932. Scottish Carboniferous Ostracoda. Transactions of the Royal Society of Edinburgh LVII, 351-95.

Lethiers, F. \& DAmotTe, R. 1993. La grande dispersion des espèces d'ostracodes (crustacea) d'eau douce à la fin de l'ère primaire. Comptes rendus de l'Académie des sciences. Série 2, Mécanique, Physique, Chimie, Sciences de l'univers, Sciences de la Terre 316, 427-33.

LogAn, B. W., REZAK, R. \& GinsburG, R. N. 1964. Classification and environmental significance of algal stromatolites. Journal of Geology 72, 68-83.

Loughlin, N. J. D. \& Hillier, R. D. 2010. Early Cambrian Teichnus-dominated ichnofabrics and palaeoenvironmental analysis of the Caerfai Group, Southwest Wales, UK. Palaeogeography, Palaeoclimatology, Palaeoeco$\log y$ 297, 239-51.

MACNEIL, A. J. \& JONES, B. 2006. Palustrine deposits on a Late Devonian coastal plain - sedimentary attributes and implications for concepts of carbonate sequence stratigraphy. Journal of Sedimentary Research 76, 292 309.

McCoY, F. 1844. A synopsis of the characters of the Carboniferous Limestone fossils of Ireland. Dublin: Dublin University Press, 207 pp.

MiI, H.-S., Grossman, E. L. \& Yancey, T. E. 1999. Carboniferous isotope stratigraphies of North America: implications for Carboniferous paleoceanography and Mississippian glaciation. Geological Society of America Bulletin 111, 960-73.

Monaghan, A. A. \& PARRish, R. R. 2005. Geochronology of Carboniferous-Permian magmatism in the Midland Valley of Scotland: implications for regional tectonomagmatic evolution and the numerical time scale. Journal of the Geological Society, London 162, 1-15.

Moore, R. C. 1961. Treatise on Invertebrate Paleontology, Pt. Q, Arthropoda 3. Lawrence, Kansas, USA: Geological Society of America and University of Kansas Press, 442 pp.

MÜLlER, G. W. 1894. Die ostracoden des Golfs von Neapel und der angrenzenden Meeres-abschitte. Fauna und Flora Neapel, Monograph 21, 404.

MÜNSTER, G. 1830. On some fossil species of Cypris and Cythere. Jahrbuch fur Mineralogie, Geognosie, Geologie und Petrefaktenkunde 1, 60-7.

Neale, J. 1984. The Ostracoda and uniformitarianism: II. The earlier record: Cretaceous to Cambrian. Proceedings of the Yorkshire Geological Society 44, 443-78.

Newman, W. A. 2005. Origin of the Ostracoda and their maxillopodan and hexapodan affinities. Hydrobiologia 538, $1-21$

OLEMPSKA, E. 1993. An ostracod assemblage from late Visean shales of the Cracow area. Acta Palaeontologica Polonica 38, 93-107.

ORR, P. J. \& BRIGGS, D. E. G. 1999. Exceptionally preserved conchostracans and other crustaceans from the Upper Carboniferous of Ireland. Special Papers in Palaeontology 62, 1-68.

Owens, B., McLean, D., Simpson, K. R. M., Shell, P. M. J. \& RoBINSON, R. 2005. Reappraisal of the Mississippian palynostratigraphy of the east Fife coast, Scotland, United Kingdom. Palynology 29, 23-47.

PARK, L. E. \& GierlowsKi-Kordesch, E. H. 2007. Paleozoic lake faunas: establishing aquatic life on land. Palaeogeography, Palaeoclimatology, Palaeoeco$\log y$ 249, 160-79.

PERYT, T. M. 1983. Classification of coated grains. In Coated Grains (ed. T. M. Peryt), pp. 3-6. Berlin: SpringerVerlag.
Pollard, J. E. 1966. A non-marine ostracod fauna from the coal measures of Durham and Northumberland. Palaeontology 9, 667-97.

Pollard, J. E. 1969. Three ostracod-mussel bands in the Coal Measures (Westphalian) of Northumberland and Durham. Proceedings of the Yorkshire Geological Society 37, 239-76.

Pollard, J. E. 1985. Coprolites and ostracods from the Dinantian of Foulden, Berwickshire, Scotland. Transactions of the Royal Society of Edinburgh: Earth Sciences 76, 49-51.

POSNER, V. M. 1966. On the sexual features of dimorphism in the representatives of the genera Lichvinella and Glyptolichvinella from the Early Carboniferous of Volhynia and Podolia. In Iskopaemye Ostrakody (ed. K. Y. Gurevitsch), pp. 34-49. Kiev.

PŘIBYL, A. 1960. New information on the Upper Carboniferous freshwater and continental fauna from the Ostrava-Karviná Coal District. Rozpravy Českoslovensé akademie věd 70, 3-71.

Retallack, G. J. 2001. Soils of the Past: An introduction to paleopedology, 2nd ed. Oxford: Blackwell Science, $404 \mathrm{pp}$.

Retrum, J. B. \& Kaesler, R. L. 2005. Early Permian Carbonitidae (Ostracoda): ontogeny, affinity, environment and systematics. Journal of Micropalaeontology 24, 179-90.

RobInson, E. 1978. The Carboniferous. In A Stratigraphical Index of British Ostracoda (eds R. H. Bate \& E. Robinson), pp. 121-66. Liverpool, UK: Geological Journal Special Issue, No. 8.

RoundY, P. V. 1926. Mississippian formations of San Saba County, Texas. United States Geological Survey Professional Paper 146, 5-8.

Salas, M. J., Vannier, J. \& Williams, M. 2007. Early Ordovician ostracods from Argentina: their bearing on the origin of binodicope and palaeocope clades. Journal of Paleontology 81, 1384-95.

SARS, G. O. 1866. Oversigt af norges marine ostracoder. Forhandlinger i Videnskabs-Selskabet i Christiania, $130 \mathrm{pp}$.

SARS, G. O. 1887. Nye bidrag til kundskaben om middelhavets invertebrafauna. Archiv for Mathematik og Naturvidenskab 12, 173-324.

SARS, G. O. 1928. An account of the crustacea of Norway with short descriptions and figures of all the specimens, vol. 9, Ostracoda. Bergen: Bergen Museum, 241-77.

SCHÄFER, P. 2007. Muschelkrebse (Ostracoden) aus permokarbonischen Karbonatbänken im rheinlandpfälzischen Teil des Saar-Nahe-Beckens. In Kohlesümpfe, Seen und Halbwüsten (eds T. Schindler \& U. H. J. Heidtke). Pollichia.

SCHALLREUTER, R. E. L. 1973. Tvaerenellidae (Ostracoda Palaeocopina) aus Backsteinkalk-Geschieben (Mittelordoviz) Norddeutschlands. Palaeontographica A 144, 55-111.

Schultze, H. P., Maples, C. G. \& Cunningham, C. R. 1994. The Hamilton Konservat-Lagerstatte: Stephanian terrestrial biota in a marginal-marine setting. Transactions of the Royal Society of Edinburgh: Earth Sciences 84, 443-51.

SCOTT, H. W. 1944. Permian and Pennsylvanian fresh-water ostracodes. Journal of Paleontology 18, 141-7.

ScOTT, H. W. 1959. Type species of Paraparchites Ulrich and Bassler. Journal of Paleontology 33, 670-4.

SEARL, A. 1991. Early Dinantian dolomites from East Fife: hydrothermal overprinting of early diagenetic fabrics? Journal of the Geological Society, London 148, 737-47. 
Siveter, D. J. 1984. Habits and modes of life of Silurian ostracodes. Special Papers in Palaeontology 32, 71-85.

SIVETER, D. J. 2008. Ostracods in the Palaeozoic? Senckenbergiana lethaea $\mathbf{8 8}, 1-9$.

Siveter, D. J. \& Williams, M. 1995. An early Cambrian assignment for the Caerfai Group of South Wales. Journal of the Geological Society, London 152, 2214.

SoHN, I. G. 1961. Family Kloedenellidae Ulrich \& Bassler, 1908. In Treatise on Invertebrate Paleontology (Q) Arthropoda 3 (ed. R. C. Moore), pp. 181-7. Lawrence, Kansas, USA: Geological Society of America and University of Kansas Press.

SoHN, I. G. 1969. Revision of some of Girty's invertebrate fossils from the Fayetteville Shale (Mississippian) of Arkansas and Oklahoma - Ostracodes. United States Geological Survey Professional Paper 606-F, 41-59.

SoHN, I. G. 1971. A revision of the Paraparchitacea (A) New Late Mississippian ostracode genera and species from Northern Alaska. United States Geological Survey Professional Paper 711-A, 1-24.

SoHN, I. G. 1972. A revision of the Paraparchitacea (B) Late Palaeozoic ostracode species from the conterminous United States. United States Geological Survey Professional Paper 711-B, 1-15.

SoHN, I. G. 1977. Muscle scars of Late Palaeozoic freshwater ostracodes from West Virginia. Journal of Research, US Geological Survey 5, 135-41.

SoHN, I. G. 1985. Latest Mississippian (Namurian A) nonmarine ostracodes from West Virginia and Virginia. Journal of Paleontology 59, 446-60.

Stanley, S. M. \& Powell, M. G. 2003. Depressed rates of origination and extinction during the late Paleozoic ice age: a new state for the global marine ecosystem. Geology 31, 877-80.

Stephenson, M. H., Williams, M., Leng, M. J. \& Monaghan, A. A. 2004a. Aquatic plant microfossils of probable non-vascular origin from the Ballagan Formation (Lower Carboniferous), Midland Valley, Scotland. Proceedings of the Yorkshire Geological Society 55, 145-58.

Stephenson, M. H., Williams, M., Monaghan, A. A., Arkley, S., SMith, R. A., DeAN, M., Browne, M. A. E. \& LENG, M. J. 2004b. Palynomorph and ostracod biostratigraphy of the Ballagan Formation, Midland Valley of Scotland, and elucidation of intraDinantian unconformities. Proceedings of the Yorkshire Geological Society 55, 131-43.

STRAND, E. 1928. Miscellanea nomenclatoria zoologica et palaeontologica. Archiv für Naturgeschichte 92, 40-1.

SwAIN, F. M. 1976. Evolutionary development of cypridopsid Ostracoda. Abhandlungen und Verhandlungen des naturwissenschaftlichen Vereins in Hamburg, Neue Folge 18/19 (Supplement), 103-19.

SWARTZ, F. M. 1936. Revision of the Primitiidae and Beyrichiidae with new Ostracoda from the Lower Devonian of Pennsylvania. Journal of Paleontology 10, 541-86.

SYlvester-Bradley, P. C. 1961. Suborder Metacopina. In Treatise on Invertebrate Paleontology, part $Q$, Arthropoda 3 (ed. R. C. Moore), p. Q358. Lawrence, Kansas, USA: Geological Society of America and University of Kansas Press.

TAYLOR, P. D. \& VINN, O. 2006. Convergent morphology in small spiral worm tubes ('Spirorbis') and its palaeoenvironmental implications. Journal of the Geological Society, London 163, 225-8.
Tibert, N. E., Colin, J.-P., Leckie, R. M., BABInot, J.-F. 2003. Revision of the ostracode genus Fossocytheridea Swain and Brown 1964: Mesozoic ancestral root for the modern eurytopic Cyprideis Jones. Micropaleontology 49, 205-30.

Tibert, N. E. \& Dewey, C. P. 2006. Velatomorpha, a new healdioidean ostracode genus from the early Pennsylvanian Joggins Formation, Nova Scotia, Canada. Micropaleontology 52, 51-66.

TIBERT, N. E. \& SCOTT, D. B. 1999. Ostracodes and agglutinated foraminifera as indicators of palaeoenvironmental change in an Early Carboniferous brackish bay, Atlantic Canada. Palaios 14, 246-60.

TREwIN, N. H. \& DAVIDSON, R. J. 1996. An Early Devonian lake and its associated biota in the Midland Valley of Scotland. Transactions of the Royal Society of Edinburgh: Earth Sciences 86, 233-46.

Turner, B. R., DEwey, C. \& FordhaM, C. E. 1997. Marine ostracods in the Lower Carboniferous fluviatile Fell Sandstone Group: evidence for base level change and marine flooding of the central graben, Northumberland Basin. Proceedings of the Yorkshire Geological Society 51, 297-306.

Turner, S., KemP, A. \& WARren, A. 1999. First early Carboniferous lungfish (Dipnoi, Ctenodontidae) from central Queensland. Alcheringa 23, 177-83.

UlRich, E. O. 1891. New and little known American Paleozoic Ostracoda, Pt. 3, Carboniferous species. Cincinnati Society of Natural History, Journal 13, 200 11.

Ulrich, E. O. \& BASSleR, R. S. 1906. New American Paleozoic Ostracoda. Notes and descriptions of Upper Carboniferous genera and species. Proceedings of the United States National Museum 30, 149-64.

Ulrich, E. O. \& BASSLER, R. S. 1908. New American Paleozoic Ostracoda. Preliminary revision of the Beyrichiidae, with descriptions of new genera. Proceedings of the United States National Museum 35, 277-340.

VAN HARTEN, D. 2000. Variable noding in Cyprideis torosa (Ostracoda, Crustacea): an overview, experimental results and a model from Catastrophe Theory. Hydrobiologia 419, 131-9.

VANNIER, J. \& ABE, K. 1995. Size, body plan and respiration in the ostracoda. Palaeontology 38, 843-73.

VAnNier, J., ThierY, A. \& Racheboeuf, P. R. 2003. Spinicaudatans and ostracods (Crustacea) from the Montceau Lagerstatte (Late Carboniferous, France): morphology and palaeoenvironmental significance. Palaeontology 46, 999-1030.

VANNIER, J., WANG, S. Q. \& COEN, M. 2001. Leperditicopid arthropods (Ordovician-Late Devonian): functional morphology and ecological range. Journal of Paleontology 75, 75-95.

WAKEFIELD, M. I. 1995. Ostracoda and palaeosalinity fluctuations in the Middle Jurassic Lealt Shale Formation, Inner Hebrides, Scotland. Palaeontology 38, 583617.

Warshauer, S. M. \& Smosna, R. 1977. Paleoecologic controls of the ostracode communities in the Tonoloway limestone (Silurian; Pridoli) of the Central Appalachians. In Aspects of Ecology and Zoogeography of Recent and Fossil Ostracoda (eds H. Löffler \& D. Danielopol), pp. 475-85. The Hague: Junk Publishers.

WEBB, J. A. 1979. A reappraisal of the palaeoecology of conchostracans (Crustacea: Branchiopoda). Neues Jahrbuch für Geologie und Palaeontologie, Abhandlungen 158, 259-75. 
WhATLEy, R. 1990a. The relationship between extrinsic and intrinsic events in the evolution of Mesozoic non-marine Ostracoda. Extinction Events in Earth's History 30, 25363.

WhATLEY, R. 1990b. Ostracoda and global events. In Ostracoda and Global Events (eds R. Whatley \& C. Maybury), pp. 3-24. Cambridge: Chapman and Hall.

WHATLEY, R. 1992. The reproductive and dispersal strategies of Cretaceous non-marine Ostracoda: the key to pandemism. In Aspects of Non-Marine Cretaceous Geology (eds N. J. Mateer \& P. J. Chen), pp. 177-92. Beijing: China Ocean Press.

Whatley, R. C. \& BALlent, S. C. 1996. In search of the earliest nonmarine cypridacean ostracods: new discoveries from the Early Mesozoic of western Argentina. GeoResearch Forum 1-2, 111-8.

Whatley, R. C., Siveter, D. J. \& Boomer, I. 1993. Arthropoda (Crustacea: Ostracoda). In The Fossil Record 2 (ed. M. J. Benton), pp. 343-56. London: Chapman and Hall.
Williams, M., Floyd, D. J., Salas, M. J., Siveter, D. J., Stone, P. \& VANNIER, J. M. C. 2003. Patterns of ostracod migration for the 'North Atlantic' region during the Ordovician. Palaeogeography, Palaeoclimatology, Palaeoecology 195, 193-228.

Williams, M., LenG, M. L., STEPHENSON, M. H., ANDREWS, J. E., Wilkinson, I. P., Siveter, D. J., Horne, D. J. \& VANNIER, J. M. C. 2006. Evidence that Early Carboniferous ostracods colonised coastal flood plain brackish water environments. Palaeogeography, Palaeoclimatology, Palaeoecology 230, 299-318.

WiLliams, M., STEPHENSON, M. H., WiLKINSON, I. P., LENG, M. L. \& Miller, C. G. 2005. Early Carboniferous (Late Tournaisian-Early Viséan) ostracods from the Ballagan Formation, central Scotland, UK. Journal of Micropalaeontology 24, 77-94.

WiLSON, R. B. 1989. A study of the Dinantian marine macrofossils of central Scotland. Transactions of the Royal Society of Edinburgh: Earth Sciences 80, 91126. 